ISSN (print): 1698-6180. ISSN (online): 1886-7995

www.ucm.es/info/estratig/journal.htm

Journal of Iberian Geology 38 (2) 2012: 429-448

http://dx.doi.org/10.5209/rev_JIGE.2012.v38.n2.40467

\title{
Palynology, Stratigraphy and Geometry of the Pennsylvanian continental Santa Susana Basin (SW Portugal)
}

\author{
Palinología, Estratigrafía y Geometría de la cuenca continental pensilvaniense de \\ Santa Susana (Suroeste de Portugal)
}

\author{
G. Machado ${ }^{1,2, *}$, I. Dias da Silva ${ }^{3}$, P. Almeida ${ }^{4,5}$ \\ ${ }^{1}$ Galp Energia E\&P, R. Tomás da Fonseca, Torre A 1600-209 Lisboa, Portugal. \\ ${ }^{2}$ Centro de Geologia da Universidade de Lisboa, Edificio C6, Campo Grande, 1749-016 Lisboa, Portugal. \\ machadogil@gmail.com \\ ${ }_{3}^{3}$ Instituto Geológico y Minero de España, Unidad de Salamanca, Calle Azafranal, 48, 1 ${ }^{\circ} \mathrm{A}$, 37001 Salamanca, España. \\ if.silva@igme.es \\ ${ }^{4}$ Centro de Geofísica de Évora, Dep. de Física da Universidade de Évora, Rua Romão Ármalo, 7000, Évora, Portugal. \\ ${ }_{5}^{5}$ Laboratorio de Investigação em Rochas Industriais e Ornamentais, Pólo de Estremoz da Universidade de Évora, \\ Convento das Maltezas, 7100-513 Estremoz, Portugal. \\ pdroalmeida@gmail.com \\ *corresponding author
}

Received: 13/01/2011 / Accepted: 15/05/2012

\begin{abstract}
The continental Pennsylvanian Santa Susana Basin (SSB) is located along an important N-S strike shear zone (Santa Susana Shear Zone - SSSZ) that separates the Ossa-Morena and South Portuguese Zones (SW Portugal). This shear zone controlled the sedimentation of the basin and probably its post-sedimentary evolution. The lower (basal) unit is mostly conglomeratic and is known essentially from drill-hole data while the upper unit, that covers most of the current surface area, is composed by sandstones, shales and some coal beds. Fluvial sedimentary rocks seem to prevail, but evidences of lacustrine sedimentation can be found in restricted areas within the upper unit. Palynological data indicate that at least part of the sedimentation took place during the Early Kasimovian (Cantabrian) but the sporomorph content of different localities suggest that significantly older sediments (Late Moscovian -Early Bashkirian) may be present. Geometrical, structural, and cartographical evidences indicate that the SSB formed as a pull-apart basin along the SSSZ and was later partially uplifted during latest Varsican and Alpine orogenies.
\end{abstract}

Keywords: Santa Susana Basin, Kasimovian, spores, pollen, pull-apart basin, SW Portugal

Resumen

La cuenca continental Pensilvaniense de Santa Susana (SSB) está localizada a lo largo de una importante zona de cizalla con dirección aproximada N-S (Zona de Cizalla de Santa Susana - SSSZ) que separa las Zonas de Ossa-Morena y Sur-Portuguesa (Su- 
roeste de Portugal). La zona de cizalla ha controlado la sedimentación en la cuenca y posiblemente su evolución post-sedimentaria. La unidad inferior (basal), estudiada fundamentalmente mediante datos de sondeos, es mayormente conglomerática, mientras que su unidad superior, que cubre actualmente una gran parte de la superficie expuesta, está compuesta por areniscas, pizarras y niveles de carbón. Las rocas de origen fluvial son las más abundantes, sin embargo existen evidencias de sedimentación lacustre en áreas muy limitadas de la unidad superior. Los datos palinológicos indican que al menos parte de la sedimentación tuvo lugar durante el Kasimoviense temprano (Cantabriense) aunque el contenido en esporomorfos de diferentes localidades sugieren la existencia de sedimentos significativamente más antiguos (Moscoviense tardio/Bashkiriense temprano). Evidencias geométricas, estructurales y cartográficas sugieren la creación de una cuenca en pull-apart a lo largo de la ZCSS.

Palabras clave: Cuenca de Santa Susana, Kasimoviense, polen, esporas, cuenca pull-apart, Suroeste de Portugal.

\section{Introduction}

The Santa Susana Basin (SSB) is a Pennsylvanian continental basin located along an important NNW-SSE to N-S shear zone (Fig. 1), the Santa Susana Shear zone (SSSZ), separating the South Portuguese Zone (SPZ) to the $\mathrm{W}$ and the Ossa-Morena Zone (OMZ) to the E (Almeida et al., 2006; Domingos et al., 1983; Oliveira et al., 2007; Sousa and Wagner, 1983). The SSSZ represents one of the southernmost branches of a regionally important shear zone, the Porto-Tomar Shear Zone (Oliveira et al., 2007; Chaminé et al., 2003 Machado et al., 2011). This geological feature was referred to as part of the Ferreira-Ficalho thrust in older literature (Gonçalves, 1983).

The SSB extends for over $15 \mathrm{~km}$ in length along a NNW-SSE direction and is 0.1 to $1 \mathrm{~km}$ wide (Fig. 1). Significant parts of the basin, mainly in its southern part, are covered by Tertiary deposits, but the true extent of the basin was revealed in the 1950s by drill-hole data. Additionally, the Pego do Altar water reservoir covered yet another part of the basin in the early 1950s. Nowadays there are 3 main outliers known, from $\mathrm{N}$ to $\mathrm{S}$, as Jongeis, Remeiras, and Vale de Figueira (Fig. 1). Other small areas exist to the $\mathrm{S}$, but most are covered by Tertiary deposits and are known mainly from borehole data.

Here we perform a reassessment of the existing borehole data in terms of basin geometry and tectonics, present new data on the available surface sections and its interpretation, and provide novel biostratigraphic data based on palynology samples from these sections.

\subsection{Geological setting}

The SSB sediments rest over two OMZ units (see Table 1), the Toca da Moura Volcano-Sedimentary Complex (Gonçalves, 1983; Machado and Hladil, 2010; Oliveira et al., 2006; Pereira et al., 2006; Santos et al., 1987 see Fig. 1) and the Grupo de Cuba Felsics, that is made of microdiorites and porphyry rocks (Gonçalves, 1983, 1984/5). The basal levels of the basin have conglomerates that contain porphyry boulders but reportedly are also cut by porphyry dykes - see Table 1 (Andrade et al., 1955; Gonçalves, 1983).

To the W, the basin is separated from the Pulo do Lobo Group units of the SPZ by the SSSZ (Almeida et al., 2006; Oliveira et al., 2007). Pulo do Lobo Group units (s.1.) include the Pulo do Lobo (phyllites, quartzites, acidic and basic metavolcanics), Ribeira de Limas (phyllites and metagreywackes), Santa Iria and Horta da Torre Formations (both formations are composed by shales, siltstones and quartzites (Garcia-Alcalde et al., 2002; Oliveira, 1983 - see Table 1). All these formations are also referred to as Ferreira-Ficalho Group (Garcia-Alcalde et al., 2002).

The basin geometry and tectonics have received little interest, despite the significant relevance of the area to the understanding of the whole region. Regional mapping conducted by the Portuguese Geological Survey (SGP/ IGM) resulted in a short note (Carvalhosa and Zbyszewsky, 1994) while a glimpse of the structure was given by Domingos et al. (1983). More recently, detailed structural and geological mapping of the northern area of the basin (Jongeis) and surrounding units has revealed a transtensional dextral tectonic style along the SSSZ resulting in the creation of a pull-apart basin during the Pennsylvanian (Almeida et al., 2006; Oliveira et al., 2007). Ongoing work in the southern parts of the basin points to a similar transtensional tectonic style related with structures equivalent to the major Porto-Tomar Shear Zone.

Dolocretes/calcretes forming a cm- to dm-thick discontinuous layer are observed in several locations covering basin rocks and surrounding Palaeozoic units. These can tentatively be associated with type I groundwater carbonates of Paleogene age defined by Pimentel et al. (1996).

\subsection{Sedimentation ages and Stratigraphy of the SSB}

The SSB has been studied since the late 1800's when fossil plants were reported and the first biostratigraphical determinations were made (Gomes, 1865; Lima, 1895/98). A series of papers by Wagner and Sousa revised the taxonomy, stratigraphic significance, and palaeobio- 


\begin{tabular}{|c|c|c|c|}
\hline Geotectonic Domain & & Lithostratigraphy & Age \\
\hline \multirow{4}{*}{ Ossa Morena Zone } & \multirow{2}{*}{$\begin{array}{l}\text { Santa } \\
\text { Susana } \\
\text { Basin }\end{array}$} & $\begin{array}{l}\text { Upper unit }(\mathrm{Qtz} / \mathrm{Qtzite}- \\
\text { rich conglomerates, sand- } \\
\text { stones, shales, coals })\end{array}$ & Kasimovian (this work) \\
\hline & & $\begin{array}{l}\text { Basal Unit (polygenic } \\
\text { conglomerates) }\end{array}$ & $\begin{array}{l}\text { (?) Moscovian-Kasimovian } \\
\text { (this work) }\end{array}$ \\
\hline & \multicolumn{2}{|c|}{$\begin{array}{c}\text { Grupo de Cuba Felsics (microdiorites } \\
\text { and porphyry rocks) }\end{array}$} & $\begin{array}{l}\text { Serpukhovain - (?)Kasimovian } \\
\text { (Priem et al., 1976) }\end{array}$ \\
\hline & \multicolumn{2}{|c|}{$\begin{array}{l}\text { Toca da Moura Complex (Slates, gre- } \\
\text { ywackes, limestones, basalts, tuffs) }\end{array}$} & $\begin{array}{c}\text { Tournaisian-Viséan } \\
\text { (Machado and Hladil, 2010; Pereira } \\
\text { et al., 2006) }\end{array}$ \\
\hline South Portuguese Zone & \multicolumn{2}{|c|}{$\begin{array}{l}\text { Pulo do Lobo Group s.l. (including } \\
\text { Pulo do Lobo, Ribeira de Limas, } \\
\text { Santa Iria and Horta da Torre Fms- } \\
\text { phyllites, quartzites, metavolcanics) }\end{array}$} & $\begin{array}{l}\text { (?) Middle Devonian to Famennian } \\
\text { (Pereira } \text { et al., 2008) }\end{array}$ \\
\hline
\end{tabular}

Table 1.- Geological units and Formations considered for this work including their age.

Tabla 1.- Unidades y Formaciones consideradas para este trabajo incluyendo sus respectivas edades.

geography of the SSB plant assemblages (e.g. Sousa and Wagner, 1983; 1985). These authors attributed the assemblages to the "very late Westphalian D or earliest Cantabrian". Cleal $(2008 \mathrm{a}, \mathrm{b})$ considered the Pennsylvanian plant assemblages from Portugal (including the SSB) and NW Spain as a discrete group with close paleobiogeographical affinities with the Rhine and Silesia Palaeoprovinces. Only two brief notes were published concerning the palynology of the basin (Fernandes, 1998; 2001). Both refer to samples derived from borehole cuttings of an unspecified locality (Fernandes, pers. com.) and the relatively diverse spore assemblage allowed an attribution to the kasimovian Miospore biozones Angulisporites splendidus - Latensina trileta (ST) and/or Thymospora obscura - T. thiessenii (OT) of Clayton et al., 1977.

The basin stratigraphy has only been summarily described in some of the previous palaeobotanical studies as well as in specific studies dealing with borehole data (Andrade, 1927/30; Andrade et al., 1955). Most studies generally refer conglomerates, sandstones, and shales with rare thin coal seams. Few paleoenvironmental interpretations have been attempted, except for the (fluvial?) continental facies. The scarcity of studies on the stratigraphy of the basin can be explained by the paucity of continuous outcrops in the area. These are restricted to some stream beds and reservoir banks.

\section{Materials and methods}

There are few localities large enough to erect lithological columns and properly interpret their sedimentary facies. A total of six localities covering the three main outliers of the basin are described. However, they do not represent the whole sequence of each area (see Fig. 1 for locations). All sections were sampled for palynology. Samples were processed using the standard palynological methods (e.g. Batten, 1999). Additionally, a mild oxidation using low concentrated bleach $(\mathrm{NaOCl})$ was performed to render some thicker-walled taxa translucent and observable under the microscope.

Further data presented here derives from the papers dealing with the extensive borehole campaign done since the 1930s up to the 1950s (Andrade 1927/30; Andrade et al., 1955) by the Portuguese Geological Survey. Unfortunately there is no further record of them in the Survey's archives, nor do the cuttings or cores seem available. The lithological columns and descriptions were systematized and used to construct cross sections in several areas of the basin (Fig. 1). Surface mapping, dips and other cartographic information was used to produce more accurate sections.

Palaeocurrent data were collected from all sections mentioned above, and also from small outcrops not logged but with enough exposure to be measured. These data derive from cross bedding structures in sandstones and fine conglomerates and from large oriented plant debris found on bedding surfaces.

\section{Results}

\subsection{Lithostratigraphy of the Santa Susana Basin}

Two major Units of the SSB were considered, as represented on the simplified geological transverses of Fig.1. 


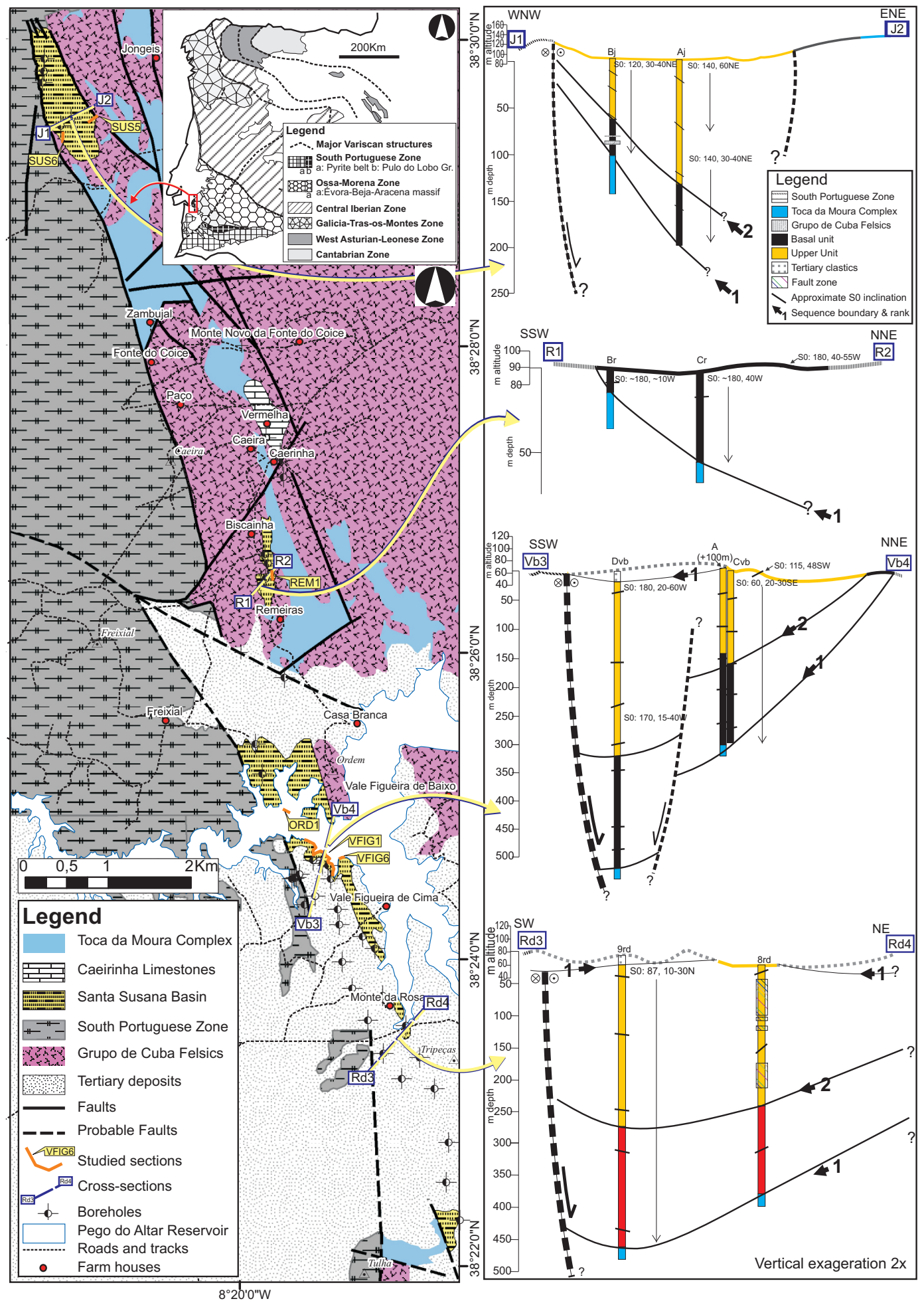

Fig. 1.- Left: Location of the study area within the Iberian Massif and geological sketch map of the three main outliers of Santa Susana basin and surrounding areas. Adapted from Andrade et al. (1955), Gonçalves (1984/5), sheet 39D of the Portuguese Geological Survey $1 / 50000$ map, Oliveira et al. (2007), Almeida et al. (2006) and unpublished data from the authors. SUS, REM, ORD, VFIG refer to surface sections (see text). Right: Simplified geological transverses from several locations in the basin. Compiled with data from Andrade et al. (1955) and unpublished data from the authors. Évora-Beja-Aracena massif includes Toca da Moura and Grupo de Cuba felsics.

Fig. 1.- Izquierda: Localización del área estudiada en el Macizo Ibérico y esbozo cartográfico-geológico de los tres principales afloramientos de la Cuenca de Santa Susana y regiones limítrofes. Adaptado de Andrade et al. (1955), Gonçalves (1984/5), hoja 39D del mapa geológico 1 / 50.000 de los Servicios Geológicos de Portugal, Oliveira et al. (2007) y Almeida et al. (2006) y datos sin publicar de los autores. SUS, REM, ORD, VFIG corresponden a secciones superficiales (ver texto). Derecha: perfiles geológicos simplificados de diferentes puntos de la cuenca. Tomado de Andrade et al. (1955) y de datos no publicados de los autores. Évora-Beja-Aracena massif incluye Complejo Toca da Moura y félsicas de Grupo de Cuba. 
They are present in several of the basin outliers, thus allowing a lateral facies correlation between them. Both units are a testimony of a two stepped stratigraphic evolution of the SSB and therefore present different sedimentary characteristics:

Basal unit composed by a very coarse grained basal conglomerate with abundant "porphyry" boulders overlain by coarse sandstones and polygenic conglomerates. Finer grained rocks and coal seams are rare. Outcrops of this unit are scarce, but they can be found in the Remeiras outlier, along the Eastern margin of the Vale de Figueira outlier and at the Southern and Southwestern margins of the Jongeis outlier (see Fig. 2).

Upper unit composed by quartz/quartzite-rich gravel conglomerates, sandstones, shales and coals. It contains all of the mined coal seams and provided all the palaeobotanical and palynological assemblages so far. This unit occupies most of the of the SSB current surface area.

The separation of the two units was subjectively defined by the dominant proportion of coarse/fine grained sedimentary rocks. The shift from a coarse-grained dominated sequence (conglomerates and sandstones) of the basal unit, to a fine-grained one (siltstones and mudstones) of the upper unit, seems rather abrupt (within a few meters) and clearly unidirectional in all instances, probably corresponding to a considerable and rapid change of the sedimentary environment.

Unfortunately, by the time the borehole campaign was performed and reports produced, the knowledge on the metamorphic facies of the basin basement rocks was scarce. Most of the lithological vocabulary used by then can be correlated with modern nomenclature, but some uncertainty remains, especially in the borehole reports of the Jongeis area.

\section{Jongeis outlier sections - SUS 5 and SUS 6}

These are small sections exposed along the bed of perennial streams and on vegetated hill slopes. In SUS 5 several badly defined dm-thick fining-upward parasequences can be observed. Gravel conglomerates grade to sandstones and mudstones (Fig. 2). Within the finer, upper part of the parasequences, thin conglomeratic beds or lenses are common. The sandstone and mudstone beds frequently show bedding-parallel lamination and are grouped in $\mathrm{cm}$ to dm-thick fining-upward parasequences (Fig. 2; Fig. 3D). SUS-6 is composed by metric conglomerate beds with thinning upward parasequences to sandstone, siltstone and mudstone. Plant imprints and coal seams are scarce. Apparently, the proportion of slate and phyllite clasts increases from bottom to top in respect to other lithologies in this section. The lowermost conglomerate beds present abundant porphyry rounded clasts, while the upper ones frequently show slate and phyllite clats, among quartz, quartzite and porphyry ones.

We suspect that SUS-5 section belongs to the Upper Unit while SUS-6 is a better fit for the Basal Unit. The classification of parasequences and its bounding surfaces in both SUS sections according to ranks or orders (Miall, 1996 - see Table 2) and the discussion on the geological processes that originated them is difficult due to the limited extent and poor preservation of the sections.

\section{Remeiras outlier section - REM}

This is a small, weathered section exposed along the bed of a perennial stream. It is attributable to the SSB Basal unit. Observational gaps are common, especially at the top of conglomeratic beds. These probably correspond to fine sandstone and mudstone levels that erode more easily. It seems that the same fining-upward parasequences observed in other sections are present, but on a sub-metrical scale. Clasts in conglomerates are variable in origin: greenish and black slates, porphyry, psamitic metasediments, quartz, quartzite, basic rocks and coal fragments. Maximum clast size varies little throughout the section $(2-4 \mathrm{~cm})$. A thin coal seam is visible at ca. 3 $\mathrm{m}$ of the base and plant fragments are commonly found in sandstone and mudstone beds. Cm- to dm-thick parasequences can be observed, especially at the top of the section. These have a conglomeratic or coarse sand base and grade to fine sand at the top (Fig. 2).

\section{Vale de Figueira outlier sections - ORD and VFIG}

\section{-Moinho da Ordem section - ORD}

A small section was logged in the northern bank of the Pego do Altar reservoir which is only observable during summer months. The section (Fig. 2) is composed by a few 1 to $3 \mathrm{~m}$ parasequences of coarse conglomerates that grade into sandstones and occasionally topped by finely laminated fine sandstone to mudstone. The clast lithologies include slate, psamitic metasediments and porphyry, but quartz and quartzite dominate throughout. Clasts are generally sub-rounded and maximum size varies considerably within and between beds (from 20 to $2 \mathrm{~cm}$ ). This section has abundant, very large, heavily oxidized plant remains, mostly impressions, preserved on bedding surfaces of sandstones. There is a clear coherent alignment of the remains. This section represents a generally coarser portion of the SSB upper unit.

\section{-Vale de Figueira sections - VFIG}

The Vale de Figueira locality is referenced in the palaeobotanical collections of the Portuguese Geological Survey Museum. At this locality there are several con- 

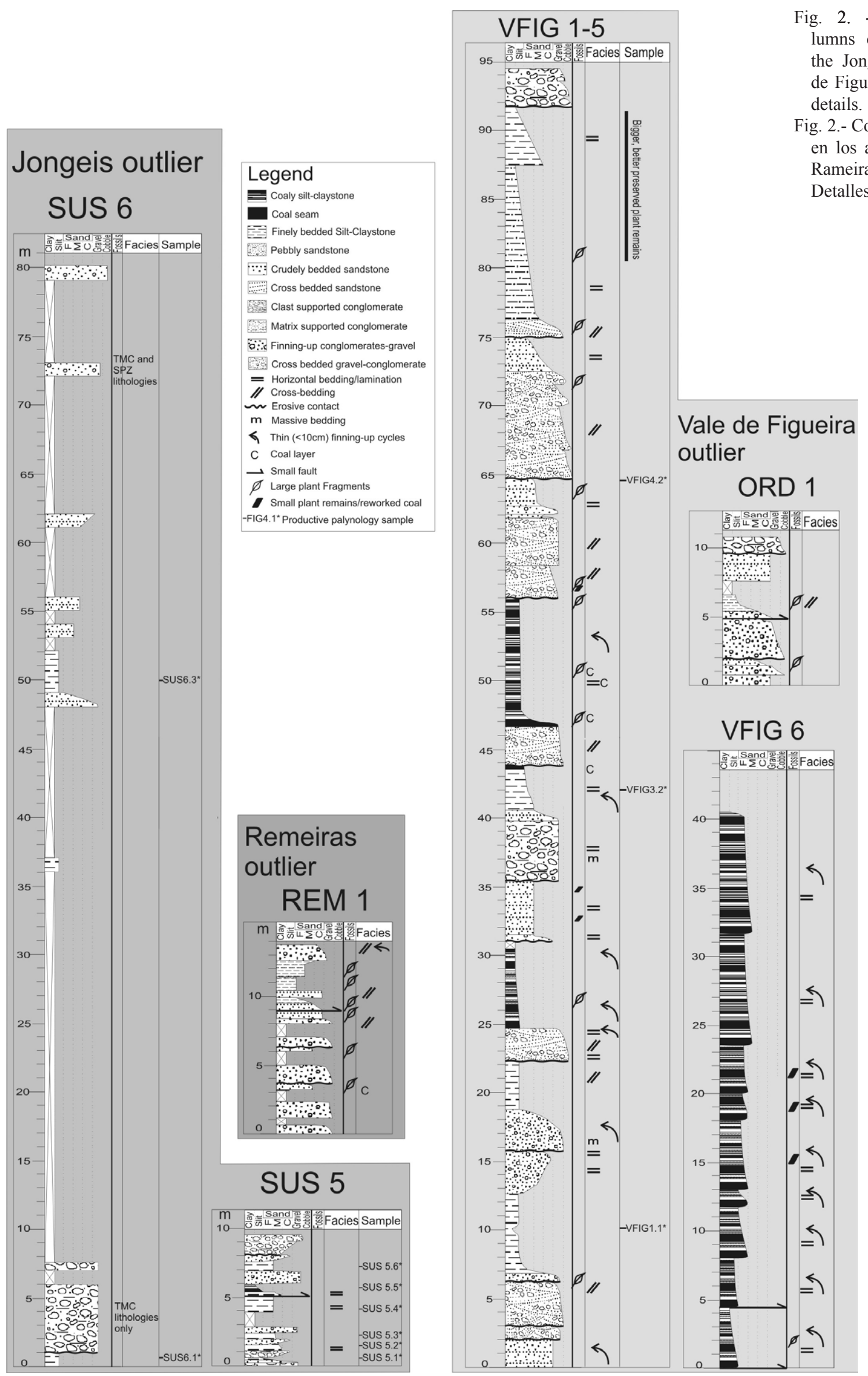
tinuous sections (up to $100 \mathrm{~m}$ thick) usually bounded by faults, but with slight internal deformation. Strong lateral variations in bed thickness and facies (few meters) can be observed where there is enough exposure.

The VFIG 1 section shows several metrical finingupward parasequences, starting with pebbly gravel conglomerates grading up to sandstones and topped by fine dark grey siltstones and shales, occasionally with coal seams (Fig. 2; Fig. 3B, E). At the base of the section, the clasts of the conglomerates have a poor roundness (angulose to sub-angulose), grains are badly sorted and several lithologies make up the clasts in similar proportion (undifferentiated slate, quartzite, quartz, micas). Matrix content is high, although all conglomerates are clast-supported. To the top of the sequence, roundness becomes gradually better (up to rounded), with a marked increase of the proportion of quartz and quartzite clasts and decrease of matrix content. This gradual change is very irregular, with some conglomeratic beds (breccias) having very-angulose clasts, erosive bases, high diversity of clast lithologies and high matrix content (e.g. intervals 65-72 $\mathrm{m}$ and 92-94 m, Fig.2). Maximum grain size remains fairly constant throughout the sequence ( 3 to $4 \mathrm{~cm}$ ). Often mudstone, sandstone and even finer conglomeratic beds show very thin fining-upward parasequences. These are 10 to $20 \mathrm{~cm}$ thick in finer conglomeratic beds, ca. $5 \mathrm{~cm}$ in sandstones and $<5 \mathrm{~cm}$ in mudstones, down to ca. $1 \mathrm{~cm}$ (Fig. 3D). This section belongs to the SSB upper unit

Plant remains are found in all lithologies, but are concentrated in the siltstones and shales, frequently as fine debris, but occasionally as large (centimetrical to decimetrical) remains (Fig. 3G). The top of the sequence is dominated by fossiliferous siltstones and shales.

Another continuous section (over $30 \mathrm{~m}$ ) in the same area (VFIG 6) is composed solely of coaly siltstones and shales. Beds are laterally continuous and often have fine bedding-parallel lamination (VFIG 6 - Fig.2). This section did not provide large, identifiable, plant remains so far. The section is bounded by faults in its base and top. This section belongs to the SSB upper unit.

\subsection{Geometry and architectural elements analysis}

To the $\mathrm{S}$ of the Remeiras outlier, borehole data show that both units of the basin are thicker in the $\mathrm{W}$, i.e. closer to the SSSZ separating the SPZ and OMZ. Bedding (S0 in Fig. 1) generally dips slightly to the W. This is very much in accordance with the model proposed by Oliveira et al. (2007) and Almeida et al. (2006) that considers a depocenter close to the SSSZ. However, in Remeiras and Jongeis outliers, the geometry is quite different as the thickest preserved sequences are to the $\mathrm{E}$ and, at least in Jongeis, bedding generally dips to the E (Fig. 1). The thickness of the basin sedimentary pile is considerably different when compared to the southern parts of the basin: $<200 \mathrm{~m}$ in Jongeis and $<75 \mathrm{~m}$ in Remeiras, compared to the $\sim 500 \mathrm{~m}$ of the Vale de Figueira outlier. Moreover, basement rocks crop out in the area between Jongeis and Remeiras outliers and the Remeiras outlier is composed solely by the basal conglomeratic unit. It is plausible to assume that post-sedimentary graben and horst tectonics played a very important role in the preservation of the basin stratigraphic record, namely the late Variscan or even Alpine orogenic events as suggested by Gonçalves (1983) and Oliveira et al. (2007). The reactivation of tectonic structures with ca. E-W and N-S trends as compressive and strike-slip faults respectively, controlled the exhumation and consequent erosion of significant parts of the $\mathrm{SSB}$, especially in the northen Jongeis and Remeiras area (see Fig.1). To the S, this tectonics controlled Tertiary sedimentation, now covering most of the SSB. It also seems that the Tertiary deposits are somewhat affected by such accidents, evidencing very recent tectonic reactivation of older fault systems. E-W trending faults typically have argillaceous and unconsolidated fault gauges. This suggests a more recent (Cenozoic) near-surface activity. N-S trending fragile structures usually have parallel lithified fault gauges with quartz veins and veinlets. These probably reactivated older fault zones. The reactivation of the SSSZ with a reverse and dextral component in its northern segment would easily explain the basin geometry observed in Jongeis and Remeiras, but evidence of this post-SSB sedimentation kinematics is unknown. Eye catching Cenozoic tectonic activity can be testified where Palaeogene calcretes/dolocretes are affected by fragile reverse faulting (Fig. 3F).

Due to the limited knowledge of the borehole data and poor exposure, the suggestion of Catuneanu (2006) is followed here and thus orders or ranks for the bounding surfaces and groups of sedimentary packages/sequences are defined.

The surface corresponding to the contact of the basin with the basement is defined as a $1^{\text {st }}$ rank boundary. It can be described from the sub-surface data for the whole basin (Fig. 1 and Table 2). This surface can rarely be observed cropping out and is sometimes tectonized. A discontinuous outcrop ca. $50 \mathrm{~m}$ to the NW of the Vale de Figueira de Baixo farm house is possibly the best example of this surface, where the basal conglomerate rests over porphyry rocks (Fig. 3C). The erosional surface at the base of the Tertiary deposits is also defined as a $1^{\text {st }}$ rank boundary. It is defined solely in the Vale de Figueira outlier and the southernmost outcrops (Fig. 1). Although this boundary corresponds to a defined cartographic geo- 


\begin{tabular}{|c|c|c|c|c|}
\hline Rank & Definition of boundaries & Sequences bounded & Possible origin & $\begin{array}{c}\text { Correlation with Miall's } \\
\text { boundary classification } \\
\text { (Miall, 1982 in Miall, } \\
\text { 1996) }\end{array}$ \\
\hline $1^{\text {st }}$ & $\begin{array}{c}\text { Lower (with basement) and } \\
\text { upper (with Tertiary deposits) } \\
\text { boundaries of the basin }\end{array}$ & $\begin{array}{c}\text { Whole basin sedi- } \\
\text { mentary sequence }\end{array}$ & $\begin{array}{c}\text { Major regional tectonic } \\
\text { processes }\end{array}$ & $8^{\text {th }}$ order \\
\hline $2^{\text {nd }}$ & $\begin{array}{c}\text { Basal unit (conglomeratic) } \\
\text { to Upper unit (sands, shales, } \\
\text { coals) transition }\end{array}$ & $\begin{array}{c}\text { Basal and Upper } \\
\text { units }\end{array}$ & $\begin{array}{c}\text { Local tectonic stasis or } \\
\text { geomorphologic evolu- } \\
\text { tion of surrounding area }\end{array}$ & $6^{\text {th }}$ or $7^{\text {th }}$ order \\
\hline $3^{\text {rd }}$ & $\begin{array}{c}\text { Erosional surfaces at the base } \\
\text { of meter-scale fining-upward } \\
\text { sequences }\end{array}$ & $\begin{array}{c}\text { Meter scale fining- } \\
\text { upward sequences }\end{array}$ & $\begin{array}{c}\text { Small local tectonic } \\
\text { pulses or channel } \\
\text { avulsion }\end{array}$ & $4^{\text {th }}$ or $5^{\text {th }}$ \\
\hline $4^{\text {th }}$ & $\begin{array}{c}\text { Bedding surfaces of intra-bed } \\
\text { fining-upward cycles (cm- to } \\
\text { dm-scale) }\end{array}$ & $\begin{array}{c}\text { cm- to dm-scale } \\
\text { fining-upward se- } \\
\text { quences }\end{array}$ & $\begin{array}{c}\text { Seasonal events (year to } \\
\text { decade scale) }\end{array}$ & $3^{\text {rd }}$ \\
\hline
\end{tabular}

Table 2.- Bounding surfaces and corresponding sequences defined for the SSB.

Tabla 2.- Superficies límite y secuencias definidas para la CSS.

logical limit, it was not observed cropping out. Considering Miall's boundary classification scheme these two boundaries would be $8^{\text {th }}$ order boundaries sensu Miall (1982 in Miall, 1996).

The boundary between the two units within the SSB is only tentatively defined as it is a rapid shift of the sedimentation characteristics and not a boundary or surface s.s.. Furthermore, it can only be generally described from the data provided by Andrade et al. (1955) in their summarized descriptions of the borehole cores (Fig. 1 and Table 2). It is classified as a $2^{\text {nd }}$ rank boundary. This surface can be tentatively associated with $6^{\text {th }}$ or $7^{\text {th }}$ order sequence boundaries sensu Miall (1982 in Miall, 1996), Table 2.

At the outcrop scale, the erosional surfaces bounding the m-scale conglomerate to mudstone parasequences (often incomplete) are present in nearly all studied sections from both basal and upper units. These are classified as $3^{\text {rd }}$ rank boundaries (Fig. 3B, E). These surfaces can be classified as $4^{\text {th }}$ or $5^{\text {th }}$ order bounding surfaces, sensu Miall (1982 in Miall, 1996), Table 2.

The bounding surfaces of the intra-bed parasequences are classified as $4^{\text {th }}$ rank boundaries. These are observed in all sections studied, mainly in sandstone, siltstone and shale beds, although some finer conglomeratic beds also showed this cyclicity (Fig. 3D). These surfaces are probably equivalent to the $3^{\text {rd }}$ order boundaries of Miall (1982 in Miall, 1996), Table 2.

Higher rank boundaries can be defined such as sets and cosets of cross-bedding structures and specific levels within beds, but this is outside the scope of this study.

Fig. 3.- (opposite page) Field photos and sedimentary features of the Santa Susana Basin (SSB). Arrows and numbers represent bounding surfaces and their rank. A - View to South of the VFIG 1 and VFIG 6 sections in the banks of the Pego do Altar reservoir; B - VFIG 1 section between 55 and $60 \mathrm{~m}$ (see Fig. 2). Note the successive erosional contacts of the gravel conglomerate beds (dotted lines interpreted as $3^{\text {rd }}$ order bounding surfaces). Hammer at the base of the first conglomeratic bed for scale; C - Basal conglomerate near the Vale de Figueira de Baixo farm house. Note the abundant porphyry clasts (pinkish colour). Hammer in the centre for scale; D - Decimetrical fining-upward cycles grading from sandstone to shale (square brackets) in SUS 5 section separated by $4^{\text {th }}$ order bounding surfaces (dotted lines); E - Metrical fining-upward cycle between 75 and $76 \mathrm{~m}$ of the VFIG 1 section. Cross lamination is visible at the top of the gravel-conglomerate bed. (Arrow and $3-3^{\text {rd }}$ order bounding surface); F - Thin calcrete cover formed over Toca da Moura and SSB rocks affected by a N-S trending fault, Vale de Figueira outlier; G - Large plant remain imprint on a bedding surface of a conglomeratic bed.

Fig. 3.- (página opuesta) Fotografías de campo y características sedimentarias de la Cuenca de Santa Susana (CSS). Flechas y números indican las superficies limitantes y su clasificación. A - Vista hacia el Sur de las secciones VFIG 1 y VFIG 6 en las orillas del embalse de Pego do Altar; B - Sección VFIG 1 entre los 55 y 60m (ver Fig. 2). De notar los sucesivos contactos erosivos de los niveles conglomeraticos (líneas punteadas) interpretados como superficies limitantes de $3^{\text {er }}$ orden). El martillo está en la base de la primera capa conglmerática sirviendo de escala; C Conglomerado de base cerca de las casas de la finca de Vale de Figueira de Baixo. Nótense los abundantes cantos de pórfiro (colores rosados). Martillo en el centro como escala; D - Ciclos decimétricos de granodecrecientes, desde arenisca a pizarra (molduras cuadradas) en la sección SUS 5, separadas por superficies limitantes de $4^{\mathrm{a}}$ orden (4 y flechas); E - Ciclo métrico de disminución de grano hacia techo entre los metros 75 y 76 de la sección VFIG 1 . A techo de la capa conglomerática se observa laminación cruzada. La línea ponteada marca una superficie limitante de $3^{\text {er }}$ orden); F - Capa fina de calcreta formada sobre las rocas de Toca da Moura y de la CSS, afectadas por una falla de dirección N-S, en el conjunto de afloramientos de Vale de Figueira; G - Marcas de restos de grandes plantas en la superficie de una capa conglomerática. 

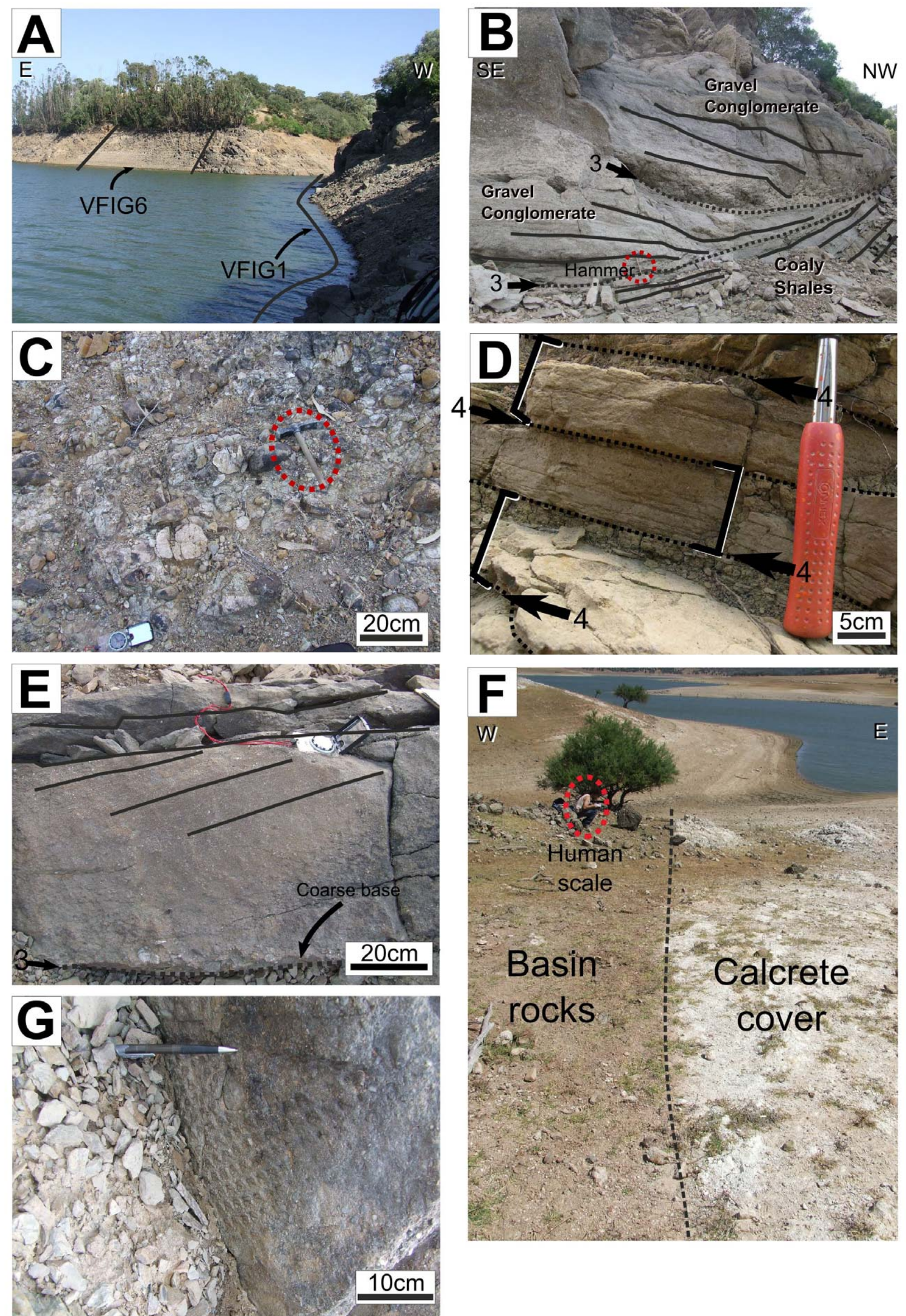


\subsection{Palaeocurrents and provenance data}

The several sections measured are probably not coeval, distance several kilometres from each other and are questionably representative of each area and time interval. The reduced number of measurements, due to the poor exposure, precludes comprehensive interpretations and firm conclusions. The upper unit with sandstones and coals is over represented due to the scarcity of outcrops of the basal unit. The main paleocurrent trends observed are to the $\mathrm{E}$, to the $\mathrm{W}$ and to the $\mathrm{S}$, which are coherent with provenance of the clasts identified in the conglomerate beds (see below and Table 3 ).

The dextral sense of the SSSZ which limits the current extent of the basin to the $\mathrm{W}$ very likely altered the original orientation of the measured planes and lineaments. The amount of its rotational (clock-wise) movement is uncertain.

The lithologies eroded and deposited in the basin are easily recognizable in the conglomeratic beds that dominate the basal unit but also appear in the upper unit. The lithologies can be associated with known units and formations in OMZ and SPZ. The basal conglomeratic unit rarely crops out, but very commonly shows large rounded boulders (up to $50 \mathrm{~cm}$ ) of the Grupo de Cuba Porphyry rocks. Several mine reports state that sills and dykes of this porphyry unit were observed to cut the basin sediments. Indeed, one of the boreholes describes two sills cutting the basal conglomeratic unit. This was never observed by us. The conglomerates in the upper unit are dominated by quartz and quartzite clasts, but other lithologies are common. These include black and greenish slates, black cherts and psamitic metasediments. Table 3 links the lithologies found and the units and formations from which they derived.

\subsection{Palynology and age of the assemblages}

Dark brown and grey shales and fine siltstones were sampled in all the described sections. Most of the processed samples were barren in terms of sporomorphs, although all yielded a significant amount of organic matter. Phytoclasts were dominant in all samples. Organic residues consistently showed signs of corrosion. Only some samples from VFIG 1, SUS 5 and SUS 6 sections provided identifiable sporomorphs (Fig. 4, 5 and 6).

Cleal $(2008 \mathrm{a}, \mathrm{b})$ suggests that macrofloral associations of Pennsylvanian Portuguese basins, including the SSB, are closely associated with the Silesian and Rhine palaeoprovinces, which includes the assemblages from Dobrudzha Coalfield (Bulgaria), SW Britain and others in Euramerica (macro and microfloral associations stu-

\begin{tabular}{|c|c|}
\hline Lithology & Probable source \\
\hline Black slate & $\begin{array}{c}\text { Série Negra - } \\
\text { Ossa Morena Zone }\end{array}$ \\
\hline Black chert & $\begin{array}{c}\text { Série Negra - } \\
\text { Ossa Morena Zone }\end{array}$ \\
\hline Greenish slate & $\begin{array}{c}\text { Toca da Moura Complex - } \\
\text { Ossa Morena Zone }\end{array}$ \\
\hline $\begin{array}{c}\text { Pink and green } \\
\text { porphyry rocks }\end{array}$ & $\begin{array}{c}\text { Grupo de Cuba Felsics - } \\
\text { Ossa Morena Zone }\end{array}$ \\
\hline $\begin{array}{c}\text { Quartz } \\
\text { hydrothermal origin) }\end{array}$ & $\begin{array}{c}\text { Pulo do Lobo Group - } \\
\text { South Portuguese Zone } \\
\text { (?)Silurian metasediments (Moura } \\
\text { schists) - Ossa Morena Zone }\end{array}$ \\
\hline Quartzite & $\begin{array}{c}\text { Toca da Moura Complex - } \\
\text { Ossa Morena Zone } \\
\text { Pulo do Lobo Group - } \\
\text { South Portuguese Zone }\end{array}$ \\
\hline Psamitic & $\begin{array}{c}\text { Pulo do Lobo Group - } \\
\text { South Portuguese Zone }\end{array}$ \\
\hline
\end{tabular}

Table 3.- Lithologies of the clasts found in the SSB's conglomerates and their probable origin.

Tabla 3.- Litología y origen probable de los clastos encontrados en los conglomerados de la CSS.

died in detail by Cleal et al. (2003); Dimitrova and Cleal (2007; 2008; Dimitrova et al. (2005). Thus, for the Santa Susana basin assemblages, the scheme proposed by Clayton et al., (1977) was used with the refinements (stratigraphic ranges of selected taxa) proposed by Cleal et al. (2003) and Dimitrova and Cleal (2008) (Fig.7).

\section{VFIG 1 section (Vale de Figueira)}

Several samples were collected from beds underlying the macroflora-rich levels (Fig. 2). From the 4 samples processed by standard palynological methods, 3 yielded identifiable palynomorphs. From this sample several slides were produced.

Their organic residues were dominated by light to dark brown phytoclasts with subordinate amounts of sporomorphs. Within the sporomorphs, large $(>80 \mu \mathrm{m})$, thin walled, laevigate and finely sculptured trilete and monolete forms were clearly dominant (ca. 45\%) Most of these forms are assignable to genera Schopfipollenites (ca. 30\%), Wilsonites and Florinites (Fig. 4 1,m; Fig. 5e, $\mathrm{m})$. Other numerically important sporomorphs within the assemblages are Cingulicavati and Crassiti infraturmae spores, namely the genera Densosporites, Lycospora and Crassispora (Table 4 and Fig. 4g, i, k). 
Sporomorph wall colour varied according to wall thickness but can be generally considered to be between 2 and 3 of the Thermal Alteration Index. Preservation of sporomorphs is moderate to good, but nearly all specimens had some corrosion features such as pitting of the wall surface, enhancement/modification of simple ornamentation (laevigate, granulate, verrucate, punctuate, etc.) or partial destruction of thin exine layers (mostly the exoexine). Such features often made difficult the recognition of trilete and monolete marks. Over 80 spore and pollen taxa were identified, although a significant number of these were left in open nomenclature due to the moderate preservation. The basal sample (VFIG 1.1) provided only a few determinable specimens while samples VFIG 3.2 and VFIG 4.2 provided hundreds of recognizable grains per slide.

The VFIG 1 section assemblages contain Cadiospora magna Kosanke, 1950 (Fig. 4b), which appears in the upper OT miospore biozone and extends into the Gzhelian (Fig.7). Significant numbers of the ST miospore biozone index species Latensina trileta Alpern, 1958 (Fig. 4o) are found and many other specimens appear to be L. trileta, but the poor preservation limits such specific determination. The presence of Latensina trileta Alpern, 1958 is recorded rarely from the Torispora securis-Torispora laevigata (SL) Miospore Biozone onwards (Clayton et al., 1977; Pittau et al., 2008), but it only becomes frequent or common in the ST zone. Angulisporites splendidus Bharadwaj, 1954 was not found. Auxiliary taxa such as Cheiledonites sp. (Fig. 4d) is represented by several specimens. Lundbladispora gigantea (Alpern) Doubinger, 1968 (Fig. 4p) is present and could indicate a Stephanian (late Kasimovian - Gzhelian) age, but it occurs in mid Westphalian D (late Moscovian) strata from the North Sea (McLean et al., 2005). The presence of cf. Reticulatisporites reticulatus Ibrahim, 1933 (Fig. 5d) is problematic as the reported range top is in the middle-upper part of the OT miospore biozone. This can be explained by intrabasinal reworking (see below). In general terms the assemblage is more characteristic of the Stephanian (late Kasimovian - Gzhelian), considering the abundance of pollen grains and the presence of typical spore taxa of this age (Fig. 7).

There is an apparent discrepancy with the biostratigraphical results derived from the palaeobotanical data (Sousa and Wagner, 1983; Mattioli et al., 2009), which point to an older age: Neuropteris ovata zones or Dicksonites plueckeneti sub zone (Fig.7) corresponding to the top of the Moscovian OT Miospore Biozone of Clayton et al., (1977). All of the fossil plant taxa described from this section have biostratigraphical ranges that reach the Cantabrian (uppermost OT - lowermost ST biozones).
Wagner and Sousa, 1983 could not exclude the possibility that the fossil plant assemblage was in fact Cantabrian (Moscovian-Kasimovian) in age.

It thus seems plausible to conclude that the VFIG 1 section is truly Stephanian (Kasimovian-Gzhelian) in age (see Fig. 7).

\section{SUS 5 and 6 sections (Santa Susana)}

Although considerably impoverished and thus difficult to interpret, it is interesting to note that pollen grains are almost absent in these assemblages (few specimens of Florinites sp. and Schopfipollenites sp. are present (Fig. 6f). Verrucosisporites spp. and Laevigatosporites spp. are dominant in both sections. The presence of Vestispora $\mathrm{cf}$. costata.(Fig. 6t); Raistrickia fulva Artuz, 1957 (Fig. 61) and Convolutispora sp. (Fig. 6a) could indicate that the assemblage is significantly older than the ST zone proposed for the VFIG 1 assemblages (see Fig. 7). Other recorded taxa such as Crassispora cf. maculosa (Knox) Sullivan, 1968 (Fig. 6c), Raistrickia cf. corynoges Sullivan, 1968 (Fig. 6m), Verrucosisporites cf. cerosus (Hoffmeister, Staplin and Maloy) Butterworth and Williams, 1958 (Fig. 6r), Trinidulus diamphidios Felix and Paden, 1964 (Fig. 6p) and Microreticulatisporites microreticulatus Knox, 1950 (Fig. 6j) have range tops in lower Westphalian or even the Mississippian. Westphalensisporites cf. irregularis Alpern, 1959 and Triquitrites cf. sculptilis Balme, 1952 (Fig. 6q) are also present, limiting the age of the assemblage to the Westphalian B (Bashkirianearly Moscovian). Due to the reduced number of specimens and moderate to poor preservation it is uncertain if these are reworked from older rocks or autochtonous sporomorphs. Several reworked palynomorphs were observed, mainly acritarchs (e.g. Veryhachium sp., Gorgonisphaeridium sp. - Fig. $6 \mathrm{u}, \mathrm{v}$ ) but these clearly have a different degree of maturation and stand out in the slides. These reworked acritarchs very likely originate from the surrounding Toca da Moura complex metasedimentary rocks (OMZ) or the SPZ Grupo do Lobo units (Santa Iria and Horta da Torre Fms.) - see Table 1, 3 and Pereira et al., 2006, 2008 for the palynology of these units.

The assemblages from the SUS 5 and SUS 6 are considered to be, provisionally, of Westphalian C or D (Moscovian) age.

\section{Discussion and Conclusions}

The limited exposure of the SSB and the restricted knowledge of its Basal Unit allow a mere generic interpretation about its stratigraphic evolution and sedimentary facies, as follows. 

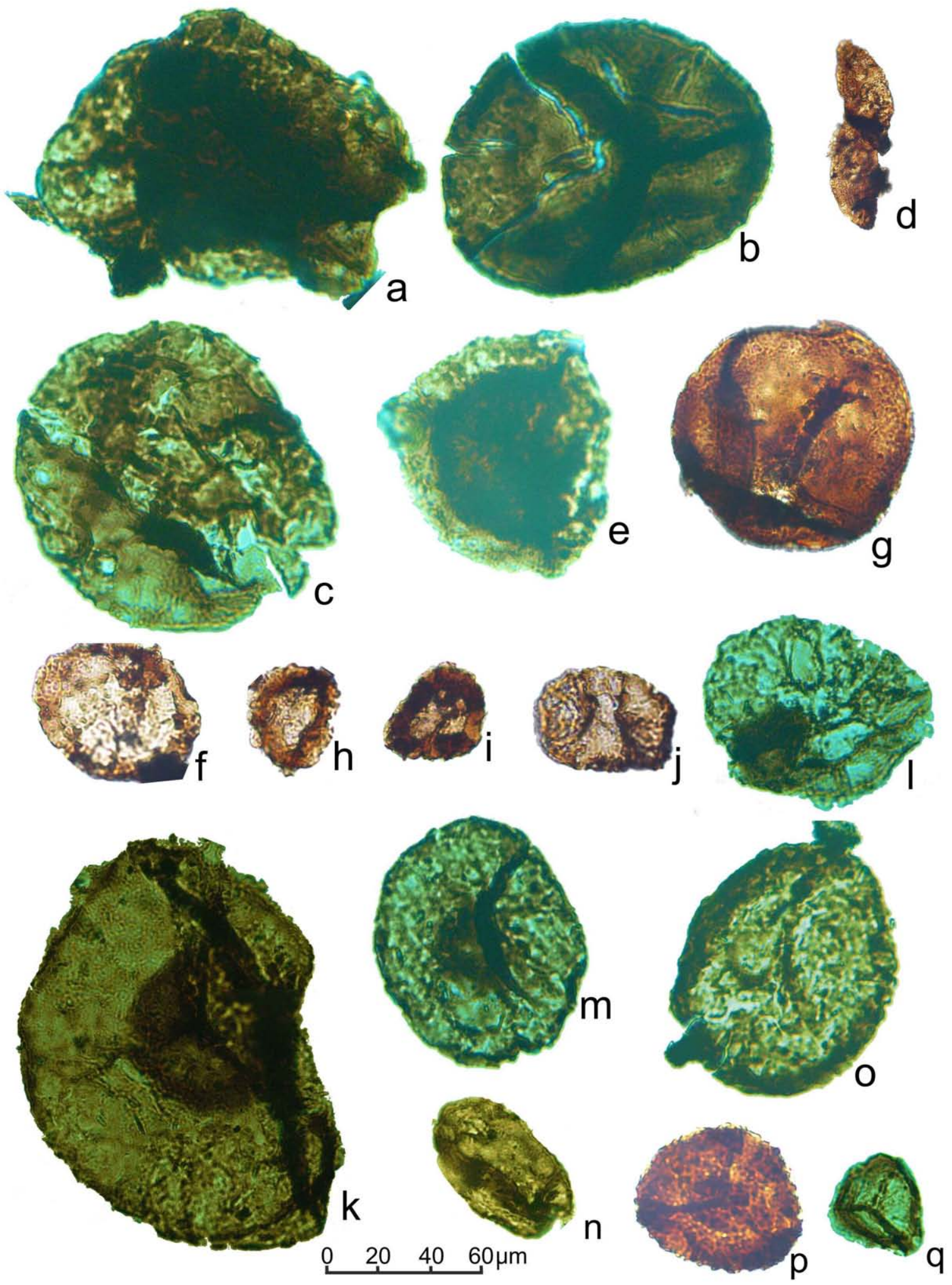

Fig. 4.- Sporomorphs from the VFIG 1 section (Vale de Figueira outlier).

Fig. 4.- Esporomorfos de la sección VFIG 1 (afloramiento de Vale de Figueira).

a - Alatisporites sp.; b - Cadiospora magna Kosanke, 1950; c - Calamospora sp. cf. C. microrugosa (Ibrahim) Schopf, Wilson and Bentall, 1944; d - Cheiledonites sp.; e - Cirratriradites sp. cf. C. elegans (Waltz) Potonié and Kremp, 1956; f - Cordaitina sp.; g - Crassispora kosankei (Potonié and Kremp) Bharadwaj, 1957; h - Densosporites gracilis Smith and Butterworth, 1967; i - Densosporites cf. pseudoanulatus; $\mathrm{j}$ - Non-striatted Disaccites pollen (unestablished systematic); k - Endosporites globiformis (Ibrahim) Schopf, Wilson and Bentall, 1944; 1 - Florinites sp. cf. F. bederi Pittau del Río, Cotza, Ronchi, Santi and Giannotti, 2008; m - Florinites sp.cf. Florinites junior Potonié and Kremp, 1954; n - Laevigatosporites sp. cf. L. vulgaris (Ibrahim) Alpern and Doubinger, 1973; o - Latensina trileta Alpern 1958; p - Lundbladispora gigantea (Alpern) Doubinger, 1968; q - Lycospora pusilla (Ibrahim) Somers, 1972 

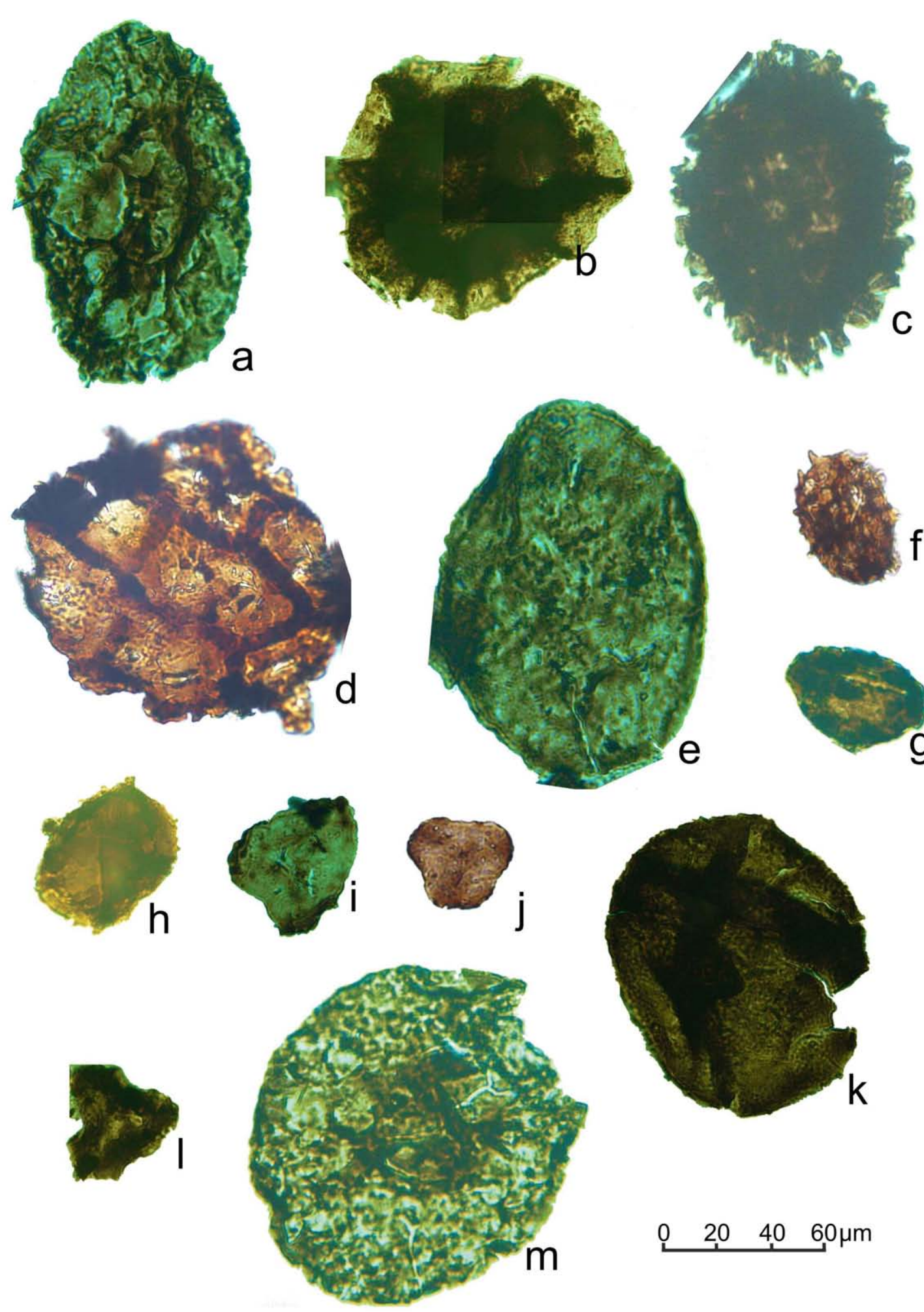

Fig. 5.- Sporomorphs from the VFIG 1 section (Vale de Figueira outlier).

Fig. 5.- Esporomorfos de la sección VFIG 1 (afloramiento de Vale de Figueira).

a - Potonieisporites sp.; b - Radiizonates tenuis (Loose) Butterworth and Smith, 1964; c - Raistrickia carbondalensis Peppers, 1970; d - cf. Reticulatisporites reticulatus; e - Schopfipollenite ellipsoides (Ibrahim) Potonié and Kremp, 1954; f - Schopfites sp.; g - Thymospora sp. cf. T. pseudothiessenii (Kosanke) Alpern and Doubinger, 1973; h - cf. Torispora securis (Balme) Alpern, Doubinger and Horst, 1973; i - Triquitrites sp. cf. desperatus Potonié and Kremp, 1955; j - Triquitrites priscus Kosanke, 1950; k - Verrucosisporites sp. cf. V. verrucosus (Ibrahim) Smith and Butterworth, 1967; 1 - Westphalensisporites irregularis Alpern, 1959; m - Wilsonites sp. cf. W. vagus Inossova, 1976. 

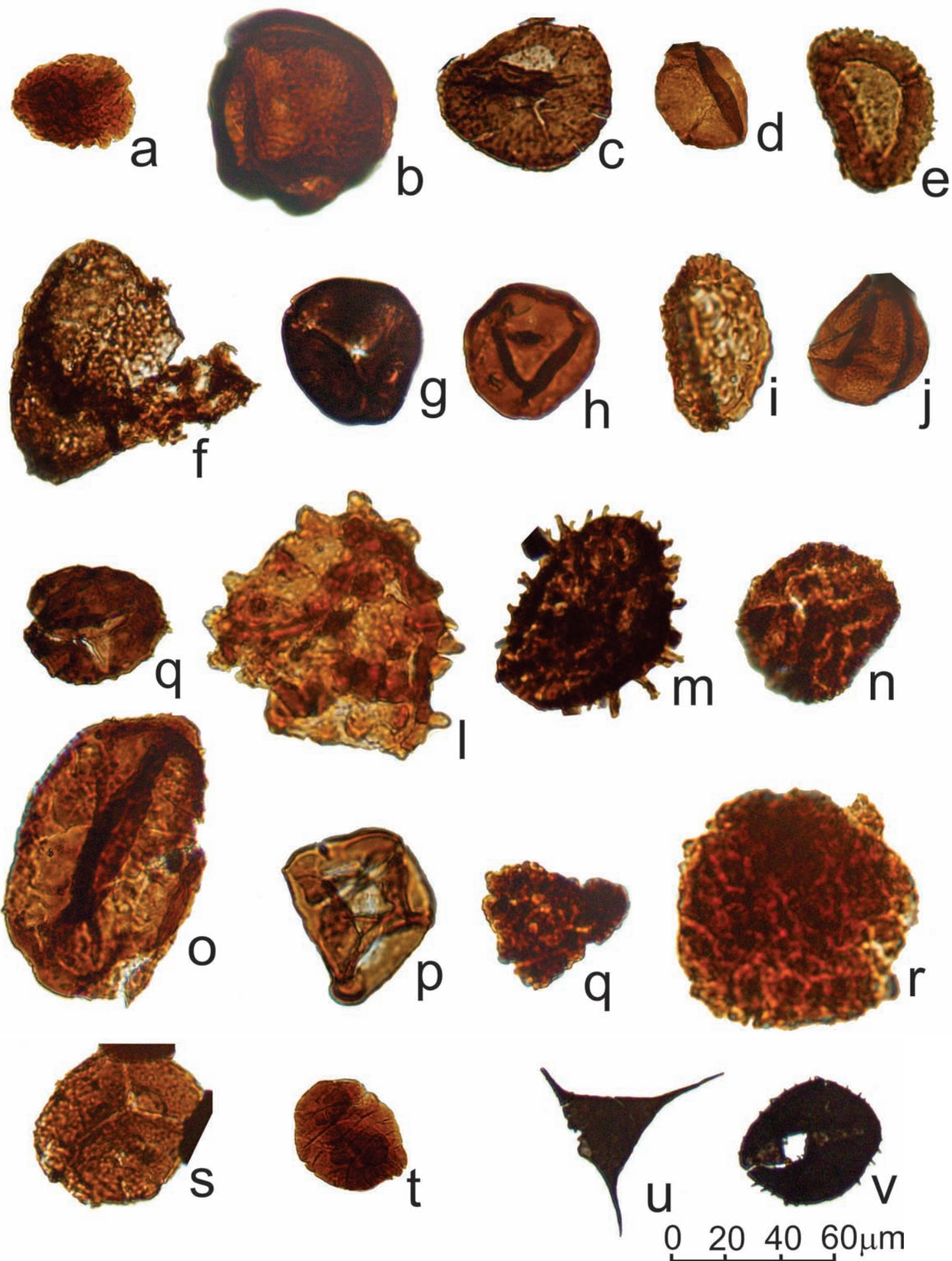

Fig. 6.- Sporomorphs from the SUS 5(a, b, d, e, i, j, o, p, t) and SUS 6 (c, f, g, h, k, l, m, n, q, r, s, u, v) sections (Jongeis outlier). u and v are reworked acritarchs.

Fig. 6.- Esporomorfos de la sección SUS 5 (a, b, d, e, i, j, o, p, t) y SUS 6 (c, f, g, h, k, l, m, n, q, r, s, u, v) (afloramiento de Jongeis). u y v son acritarcas removilizados.

a - Convolutispora sp.; b - Crassispora kosankei (Potonié and Kremp) Bharadwaj, 1957; c - Crassispora sp. cf. C. maculosa; d - Cyclogranisporites sp.; e - Densosporites sp. cf. D. lobatus Kosanke, 1950; f - Florinites sp.; g - Granulatisporites sp.; h - Laevigatosporites minimus (Wilson and Coe) Schopf, Wilson and Bentall, 1944; i - Lycospora sp. aff. L. pusilla (Ibrahim) Somers, 1972; j - Microreticulatisporites microreticulatus Knox; k - Pustulatisporites sp.; 1 - Raistrickia fulva Artuz, 1957; m - Raistrickia sp. cf. R. corynoges Sullivan, 1968; n - ? Savitrisporites sp.; o - Schopfipollenites sp.; p - Trinidulus diamphidios Felix and Paden, 1964; q - Triquitrites sp. cf. T. sculptilis Balme, 1952; r - Verrucosisporites sp. cf. V. cerosus (Hoffmeister, Staplin and Maloy) Butterworth and Williams, 1958; s - Verrucosisporites cf. pergranulus (Alpern) Smith and Alpern, 1971; t - Vestispora sp. cf. V. costata (Balme, 1952) Spode in Smith and Buterworth 1967; u - Veryhachium sp.; v - Gorgonisphaeridium sp. 


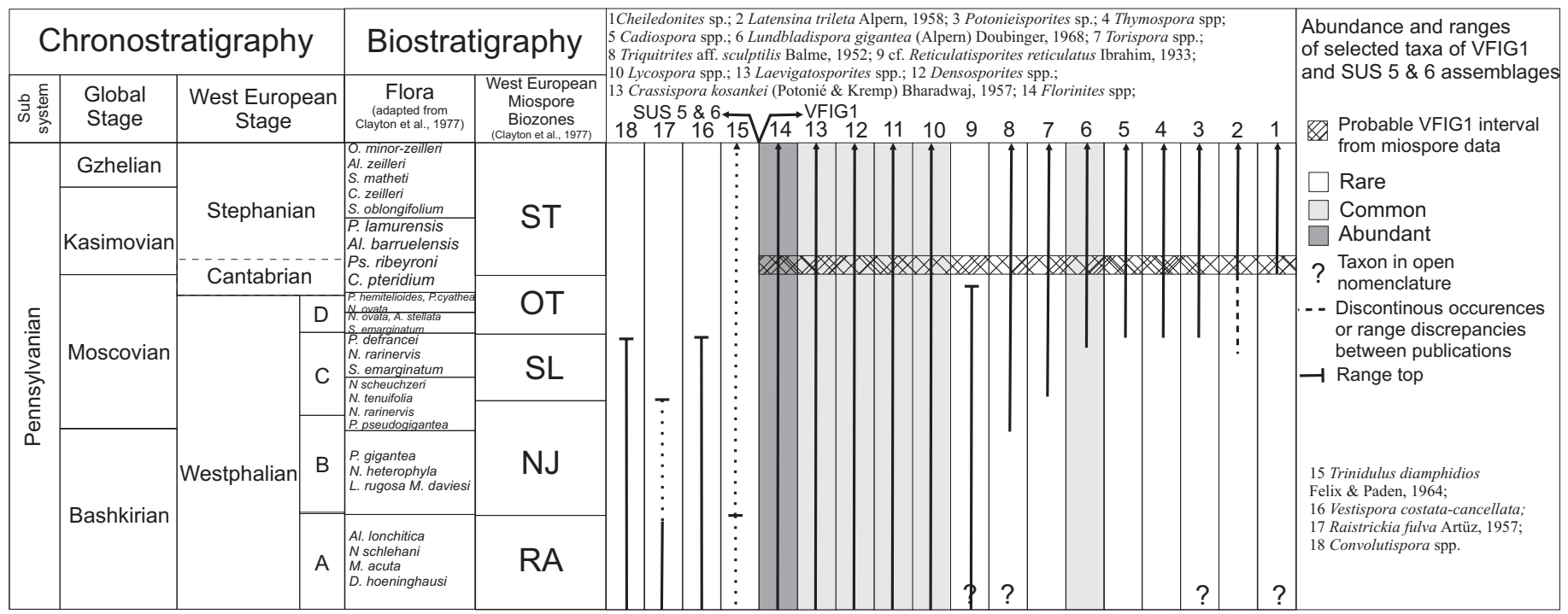

Fig. 7.- Range of selected taxa from the VFIG 1, SUS 5 and SUS 6 sections and possible biostratigraphical positioning (cross hatch). "?" denotes taxon in open nomenclature. Dashed line denotes infrequent occurrence or discrepancy between ranges reported by different authors. Ranges and biozonations compiled from Alpern et al. (1967); Alpern and Liabeauf (1967); Clayton et al. (1977) and Mclean et al. (2005).

Fig. 7.- Rango y posible posición bioestratigráfica (rayado cruzado) de los taxones en las secciones VFIG 1, SUS 5 y SUS 6 (bandas con rayado oblicuo). El símbolo "?" expresa una nomenclatura abierta para los taxones. La línea discontinua indica una ocurrencia baja o discrepancia en los rangos publicados por diferentes autores. Rangos y biozonas compilados de Alpern et al. (1967); Alpern y Liabeauf (1967); Clayton et al. (1977) y Mclean et al. (2005).

The SSB's $1^{\text {st }}$ rank boundaries (Table 2; Fig. 1) are probably linked to a major regional tectonic process occurred during the Variscan orogeny. Such activity promoted the appearance of topographic highs with the gradual exhumation of the OMZ volcanics to the East and the metamorphosed SPZ slates and quartzites to the W, and trenches along the SSSZ that were filled with detritus derived from the erosion of the neighbouring units (Almeida et al., 2006; Oliveira et al., 2007, see Geological setting above). The erosional surface at the base of the Tertiary deposits ( $1^{\text {st }}$ rank boundary) is possibly related to the uplift and erosion of the basin and surrounding area. The post-Pennsylvanian uplift is related with a horst and graben tectonics, controlled by the synchronous activity of two different tectonic features: the dextral-reverse reactivation of older dextral-normal N-S trending faults and; the development of fragile E-W faults (Gonçalves, 1983). The $2^{\text {nd }}$ rank boundary between the two units within the SSB (Table 2; Fig. 1) is probably related to a tectonic stasis or period of milder activity that promoted a the shift from a stage dominated by coarse polimitic sediments to a stage that also includes fine sediments related with the appearance of perennial lakes and peat formation. This change can also reflect a simple geomorphological change of the surrounding area as the topographic highs were eroded.

The $3^{\text {rd }}$ rank erosional surfaces defining the boundary between $\mathrm{m}$-scale conglomerate to mudstone parasequenc- es (Fig. 3B, E; Table 2) are possibly connected with small tectonic pulses affecting the area. The changes in the clasts' lithologies and roundness from one parasequence to the next suggest changes of source areas. Alternatively, these parasequences and corresponding erosional surfaces can merely be related with the fluvial processes such as channel avulsion (Jones and Schumm, 1999).

The $4^{\text {th }}$ rank boundaries surfaces of the intra-bed parasequences (Fig. 3D; Table 2) are probably related with seasonal parasequences and/or with anual or decade scale events such as floods.

The lithological and palynological data point to a strictly terrestrial sedimentation, most likely fluvial in the Upper Unit, and somewhat more alluvial in the Basal Unit. The cyclic nature of the sedimentary sequences, the considerable lateral facies variations and the association of texturally immature gravel conglomerates with sandstones, shales (frequently with plant remains) and coals strongly suggests a fluvial (meandering?) system with associated flood plain and/or abandoned channel sedimentation. During the later stages of the basin evolution (corresponding to the upper unit), perennial lakes developed in some areas (e.g. VFIG 6 section).

Considering the geometry of the basin, palaeocurrent and provenance data, it is evident that both SPZ and OMZ rocks were exposed and eroded during the SSB infill. During the initial stages of the basin filling, the surrounding landscape was very likely dominated by the Grupo 
de Cuba felsic rocks, as they make up the vast majority of the basal conglomerate clasts. The magmatic event that originated these acid rocks may have been active at least until the early times of this basin sedimentation history. This fact is emphasized by the presence of the felsic dykes described in the borehole core data.

Several controls acted on the basin sedimentation. Periodical large scale tectonic events promoted the formation of a depocenter along the SSSZ and the consequent onset of sedimentation.

According to Pereira et al. (2008) the sedimentary system, whose proximal portion is represented by the SSB, was likely connected to the flysch sedimentation in the SPZ occurring to the W and SW, during the Mississippian and Pennsylvanian, at least in the Moscovian (OT miospore biozone). It is unclear if this connection was via a bypass zone or if the SSB extended over a much larger area which was later eroded.

The tectonic activity that gave rise to the development of the SSB persisted until early stages of post-SSB sedimentation. However it was during the Meso(?)-Cenozoic that the basin was increasingly exposed and eroded, especially in the northern parts. The basin was covered by up to $20 \mathrm{~m}$ of Tertiary deposits in the southern area. This phenomenon, that favored the preservation of this part of the basin, is apparently associated to graben and horst alpine tectonics along N-S and E-W fragile faults, as suggested by the cartographic geologic pattern and by the field relations between Tertiary deposits, the calcretes and their Paleozoic basement (Fig. 1; Fig. 3F).

The age of the basin can only be bracketed for part of the upper unit. The VFIG 1 section provided a sporomorph assemblage assignable to the Kasimovian = "Early Stephanian" ST miospore biozone of Clayton et al., (1977). Previous records from an unspecified locality (Fernandes, 1998, 2001) provided similar results. The assemblages from SUS 5 and 6 sections suggest that significantly older sediments may be present, but the poor quality of the residues preclude further interpretations. Further investigation of the basin palynology is needed to assess the true extent in time of its sedimentation.

\section{Acknowledgements}

G. Machado acknowledges the Geoscience Department of Aveiro University and GeoBioTec for the logistical support; the Fundação para a Ciência e a Tecnologia PhD grant SFRH/BD/23787/2005. P. Almeida acknowledges CEVALOR (Centro Tecnológico para o Aproveitamento e Valorização das Rochas Ornamentais e Industriais) for the logistical support. Oficinas do Convento (Montemoro-Novo) are acknowledged for the logistical support.

\section{References}

Almeida, P., Silva, Í., Oliveira, H. (2006): Caracterização TectonoEstratigráfica da Zona de Cisalhamento de Santa Susana (ZCSS) no Bordo SW da Zona de Ossa Morena (ZOM), (Portugal). Livro de Resumos do VII Congresso Nacional de Geologia, Estremoz: 49-53.

Alpern, B., Lachkar, G., Liabeuff, J. J. (1967): Le bassin houiller Lorrain peut-il fournir un stratotype pour le Westphalien supérieur. Review of Palaeobotany and Palynology (5), 75-91. doi: 10.1016/0034-6667(67)90210-2.

Alpern, B., Liabeuff, J. J. (1967): Considérations palynologiques sur le Westphàlien et le Stéphanien: propositions pour un parastratotype. Comptes Rendu Academie Sciences Paris serie D 265, 840-843.

Andrade, C. (1927-30): Alguns elementos para o Estudo dos Depósitos de Carvão do Moinho da Ordem. Comunicações Geológicas $16,3-28$.

Andrade, C., Santos, R., Cabral Guerreiro, A. (1955): Estudo por sondagens da região carbonífera do Moinho da Ordem. Comunicações dos Serviços Geológicos de Portugal 36, 199-255.

Batten, D. J. (1999): Small palynomorphs. In: T. P. Jones, N. P. Rowe (eds.), Fossil plants and spores: modern techniques. Geological Society, London: 15-19.

Carvalhosa, A., Zbyszewsky, G. (1994): Notícia Explicativa da folha 35-D (Montemor-o-Novo) da Carta Geológica de Portugal à escala 1:50.000. Instituto Geológico e Mineiro, 86 p.

Catuneanu, O. (2006): Principles of Sequence Stratigraphy. Elsevier, Amsterdam: $375 \mathrm{p}$.

Chaminé, H. I., Gama Pereira, L. C., Fonseca, P. E., Moço, L. P., Fernandes, J. P., Rocha, F., Flores, D., Pinto de Jesus, A., Gomes, C., Soares de Andrade, A. A., Araújo, A. (2003): ectonostratigraphy of middle and upper Palaeozoic black shales from the Porto-TomarFerreira do Alentejo shear zone (W Portugal): new perspectives on the Iberian Massif. Geobios 36, (6), 649-663. doi: 10.1016/j.geobios.2003.03.002.

Clayton, G., Coquel, R., Doubinger, J., K.J., G., Loboziak, S., Owens, B., Streel, M. (1977): Carboniferous Miospores of Western Europe: illustration and zonation. Mededelingen Rijks Geologische Dienst 29, 1-71.

Cleal, C. J. (2008a): Palaeofloristics of Middle Pennsylvanian lyginopteridaleans in Variscan Euramerica. Palaeogeography, $\mathrm{Pa}$ laeoclimatology, Palaeoecology 261, (1-2), 1-14. doi: 10.1016/j. palaeo.2007.12.010.

Cleal, C. J. (2008b): Palaeofloristics of Middle Pennsylvanian medullosaleans in Variscan Euramerica. Palaeogeography, Palaeoclimatology, Palaeoecology 268, (3-4), 164-180. doi: 10.1016/j.palaeo.2008.03.045

Cleal, C. J., Dimitrova, T. K., Zodrow, E. L. (2003): Macrofloral and palynological criteria for recognising the Westphalian-Stephanian boundary. Newsletters on Stratigraphy 39, (2/3), 181-208.

Dimitrova, T. K., Cleal, C. J. (2007): Palynological evidence for late Westphalian-early Stephanian vegetation change in the Dobrudzha Coalfield, NE Bulgaria. Geological Magazine 144, (03), 513-524. doi: $10.1017 / \mathrm{S} 0016756807003378$.

Dimitrova, T. K., Cleal, C. J. (2008): The late Westphalian D - Early Cantabrian palynology of Europe and the Canadian maritimes. Geosciences. Proceedings of the National Conference with international participation, Sofia: 61-62.

Dimitrova, T. K., Cleal, C. J., Thomas, B. A. (2005): Palynology of late Westphalian-early Stephanian coal-bearing deposits in the eastern South Wales Coalfield. Geological Magazine 142, (06), 809821. doi: 10.1017/S001675680500107X.

Domingos, L. C. G., Freire, J. L. S., Silva, F. G., Gonçalves, F., Pereira, E., Ribeiro, A. (1983): The Structure of the Intramontane Upper 
Carboniferous Basins in Portugal. In: M. J. Lemos de Sousa, J. T. Oliveira (eds.), The Carboniferous of Portugal. Memorias, Nova Série 29, Serviços Geológicos de Portugal, Lisboa: 187-194.

Fernandes, J. P. (1998a): Nuevos resultados del estudio palinológico de la Cuenca de Santa Susana (Alcácer do Sal, Portugal). In: M. A. Fombella Blanco, Fernandez González, D., Valença Barrera, R.M. (eds.), Palinología: Diversidad y Aplicaciones, Trabajos del XII Simposio de Palinología (A.P.L.E.), León, 1998. Universidad de León, 95-99.

Fernandes, J. P. (1998b): Resultados preliminares del estudio palinológico de la Cuenca de Santa Susana (Alcácer do Sal, Portugal), Estudios palinológicos. Actas XI Simposio de Palinología A.P.L.E., Alcalá de Heranes: p. 3.

Garcia-Alcalde, J., Carls, P., Pardo-Alonso, M., Sanz-Lopez, J., Soto, F., Truyols-Massoni, M., Valenzuela-Ríos, J. (2002): Devonian. In: W. Gibbons, T. Moreno (eds.), The Geology of Spain. Geological Society, London: 67-92.

Gomes, B. A. (1865): Flora fóssil do terreno carbonífero das visinhanças do Porto, Serra do Bussaco e Moinho d'Ordem próximo de Alcácer do Sal. Commissão Geológica de Portugal. Memória 46 p.

Gonçalves, F. (1983): Formações Precâmbricas e do Paleozóico Superior do Flanco Meridional do Anticlinório de Évora - Moura, Dia 29 de Setembro (Excursão n²), Guia das Excursões no bordo sudoeste da Zona de Ossa-Morena. Comunicações dos Serviços Geológicos de Portugal 69 (2), 267-282.

Gonçalves, F. (1984/85): Contribuição para o conhecimento geológico do complexo vulcano-sedimentar de Toca da Moura, Alcácer do Sal. Memórias da Academia das Ciências de Lisboa 26, 263-267.

Jones, L. S., Schumm, S. A. (1999): Causes of avulsion: an overview. In: N. S. Dwight, J. Rogers (eds.), Fluvial sedimentology, Special Publications. 28, International Association of Sedimentologists, 171-178.

Lima, W. (1895-1898): Estudo sobre o carbónico do Alentejo. Communicações da Direcção dos Trabalhos Geológicos de Portugal 3, 34-54.

Machado, G., Francu, E., Vavrdová, M., Flores, D., Fonseca, P. F., Rocha, F., C., L., Gama Pereira, L. C., Gomes, A., Fonseca, M., Chaminé, H. I. (2011): Stratigraphy, palynology and organic geochemistry of the Devonian-Mississippian metasedimentary Albergaria-a-Velha Unit (Porto-Tomar shear zone, W Portugal). Geological Quarterly 55 (2), 139-164.

Machado, G., Hladil, J. (2012): On the age and significance of the limestone localities included in the Toca da Moura volcano-sedimentary complex: preliminary results. III Congresso Iberico de Paleontologia / XXVI Jornadas de la Sociedad Espanola de Paleontologia, Lisboa: 153-156.

Mattioli, M., Machado, G., Dias da Silva, Í., Almeida, P. (2009): Revision of the stratigraphy and palaeobotany of the Moscovian (Upper Carboniferous intramontane Santa Susana Basin (SW Portugal). Paleolusitana 1, 269-275.

Mclean, D., Owens, B., Neves, R. (2005): Carboniferous miospore biostratigraphy of the North Sea. In: J. D. Collinson, D. J. Evans, D. W. Holliday, N. S. Jones (eds.), Carboniferous hydrocarbon geo- logy: the southern North Sea and surrounding onshore areas. 7, Yorkshire Geological Society, 13-24.

Miall, A. (1996): The geology of fluvial deposits: sedimentary facies, basin analysis and petroleum geology. Springer-Verlag, Berlin: $582 \mathrm{p}$.

Oliveira, H., Silva, Í., Almeida, P. (2007): Tectonic and Stratigraphic description and mapping of the Santa Susana Shear Zone (SSSZ), the SW Border of Ossa Morena Zone (OMZ), Barrancão - Ribeira de S. Cristóvão Sector (Portugal): Theoretical Implications. Geogaceta 41 (3-6), 151-154.

Oliveira, J. T. (1983): The marine Carboniferous of south Portugal: A stratigraphic and sedimentological approach. . In: M. J. Lemos de Sousa, J. T. Oliveira (eds.), The Carboniferous of Portugal. Memorias, Nova Série 29, Serviços Geológicos de Portugal, Lisboa: 3-38.

Oliveira, J. T., Relvas, J. M. R. S., Pereira, Z., Munhá, J. M., Matos, J. X., Barriga, F. J. A. S., Rosa, C. J. (2006): O complexo vulcano-sedimentar de Toca da Moura-Cabrela, Zona de Ossa Morena : evolução tectono-estratigráfica e mineralizações associadas. In: R. Dias, A. Araújo, P. Terrinha, J. C. Kullberg (eds.), Geologia de Portugal no Contexto da Ibéria. Universidade de Évora, Évora: 207-243.

Pereira, Z., Matos, J. X. D., Fernandes, P., Oliveira, T. (2008): Palynostratigraphy and systematic palynology of the Devonian and Carboniferous Successions of the South Portuguese Zone, Portugal. Memórias Geológicas 34, 181 p.

Pereira, Z., Oliveira, V., Oliveira, J. T. (2006): Palynostratigraphy of the Toca da Moura and Cabrela Complexes, Ossa Morena Zone, Portugal. Geodynamic implications. Review of Palaeobotany and Palynology 139, (1-4), 227-240. doi: 10.1016/j.revpalbo.2005.07.008.

Pimentel, N. L., Wright, V. P., Azevedo, T. M. (1996): Distinguishing early groundwater alteration effects from pedogenesis in ancient alluvial basins: examples from the Palaeogene of southern Portugal. Sedimentary Geology 105, (1-2), 1-10. doi: 10.1016/00370738(96)00034-6.

Pittau, P., Del Rio, M., Cotza, F., Ronchi, A., Santi, G., Giannotti, R. (2008): Pennsylvanian miospore assemblages from the Bèdero Section, Varese, Italian Southern Alps. Revue de Micropaléontologie 51, (2), 133-166. doi: 10.1016/j.revmic.2007.11.001.

Priem, H. N. A., Boelrijk, N. A. I. M., Hebeda, E. H., Verdumen, E. A. T., Verchure, R. A. (1976): Isotopic dating in Southern Portugal. ECOG IV volume of abstracts: Amsterdam.

Santos, J., Mata, J., Gonçalves, F., Munhá, J. (1987): Contribuição para o conhecimento Geológico-Petrológico da Região de Santa Susana: O Complexo Vulcano-sedimentar da Toca da Moura. Comunicações dos Serviços Geológicos de Portugal 73 (1-2), 29-48.

Sousa, J. L., Wagner, R. H. (1983): General Description of the Terrestrial Carboniferous Basins in Portugal and History of Investigations. In: M. J. Lemos de Sousa, J. T. Oliveira (eds.), The Carboniferous of Portugal. Memorias, Nova Série 29, Serviços Geológicos de Portugal, Lisboa: 117-126.

Sousa, J. L., Wagner, R. H. (1985): Annoted Catalogue of the Bernardino António Gomes fossil plant collection on Lisbon. Anais da Faculdade de Ciencias. Universidade do Porto. Papers on the Carboniferous of the Iberian Peninsula. Supplement to volume 64, (1983), 411- 434. 


\section{Appendix 1 Systematic Palynology}

For the systematic palynology the Turmal System proposed by Potonié (1970) with modifications by Traverse (2007) is followed. The frequency of each taxon is indicated as well as the section where it occurs. The statistical significance of the frequency of sporomorphs in VFIG 1 section is high as several hundreds of specimens were counted. For the SUS 5 and SUS 6 sections, the significance is much lower as the total number of specimens in each section is below 100 . Consequently the abundance categorization is not shown for these sections. The frequency ranges of Smith and Butterworth (1967) were applied and are summarized in the following table:

$\begin{array}{ll}\text { Rare } & <0,5 \% \\ \text { Frequent } & 0,5-2 \% \\ \text { Common } & 2,1-5 \% \\ \text { Very common } & 5,1-10 \% \\ \text { Abundant } & >10 \%\end{array}$

Anteturma SPORITES Potonié, 1893

Turma TRILETES Dettmann, 1963

Subturma AZONOTRILETES Dettmann, 1963

Infraturma LAEVIGATI Potonié, 1956

Genus Calamospora (Ibrahim) Schopf, Wilson and Bentall, 1944

Occurrence: Frequent in all sections

Calamospora sp. cf. C. microrugosa (Ibrahim) Schopf, Wilson and Bentall, 1944 (Fig. 4c)

Occurrence: rare in VFIG 1

Calamospora cf. parva Guennel, 1958

Occurrence: rare in VFIG 1

Calamospora aff. pusilla Peppers, 1970

Occurrence: rare in VFIG 1

Calamospora spp.

Occurrence: rare in VFIG 1 and present in SUS 5

Genus Leiotriletes Potonié and Kremp, 1954

Occurrence: frequent in VFIG 1, present in SUS 5

Leiotriletes levis (Kosanke) Potonié and Kremp, 1955

Occurrence: rare in VFIG 1

Leiotriletes sp.

Occurrence: rare in VFIG 1, present in SUS 5

Genus Punctatisporites (Ibrahim) Potonié and Kremp, 1954

Occurrence: rare in VFIG 1, present in SUS 5

Punctatisporites provectus Kosanke, 1950

Occurrence: rare in VFIG 1

Punctatisporites sp. (Fig. 6k)

Occurrence: present in SUS 5

Infraturma APICULATI Potonié, 1956

Subinfraturma GRANULATI Dybová and Jachowicz, 1957

Genus Cyclogranisporites Potonié and Kremp, 1954

Occurrence: rare in VFIG 1, present in SUS 6

aff. Cyclogranisporites breviradiatus Peppers, 1970

Occurrence: rare in VFIG 1

Cyclogranisporites sp. (Fig. 6d)

Occurrence: present in SUS 6

Genus Granulatisporites Potonié and Kremp, 1954

Occurrence: frequent in VFIG 1 and present in SUS 5

Granulatisporites sp. cf. G. granularis Kosanke, 1950

Occurrence: rare in VFIG 1

Granulatisporites spp. (e.g. Fig. 6g)

Occurrence: frequent in VFIG 1 and present in SUS 5
Subinfraturma VERRUCATI Dybová and Jachowicz, 1957

Genus Converrucosisporites Potonié and Kremp, 1954

Occurrence: frequent in VFIG 1

Converrucosisporites aff. armatus (Dybóva and Jachowicz) Smith and Butterworth, 1967

Occurrence: frequent in VFIG 1

Genus Schopfites Kosanke, 1950

Occurrence: rare in VFIG 1

Schopfites sp. (Fig. 4f)

Occurrence: rare in VFIG 1

Genus Verrucosisporites (Ibrahim) Smith and Butterworth, 1967

Occurrence: common in VFIG 1 and present in SUS 5 and 6

Verrucosisporites cf. cerosus (Hoffmeister, Staplin and Maloy) Butterworth and Williams, 1958 (Fig. 6r)

Occurrence: frequent SUS 5

Verrucosisporites sp. cf. V. microtuberosus (Loose) Smith and Butterworth, 1967

Occurrence: rare in VFIG 1

Verrucosisporites papulosus Hacquebard, 1957

Occurrence: rare in VFIG 1

Verrucosisporites sp. cf. V. pergranulus (Alpern) Smith and Alpern, 1971 (Fig. 6s)

Occurrence: rare in VFIG 1 and present in SUS 5

Verrucosisporites sp. cf. V. verrucosus (Ibrahim) Smith and Butterworth, 1967 (Fig. 5k)

Occurrence: common in VFIG 1

Verrucosisporites spp.

Occurrence: common in VFIG 1 and present in SUS 5 and 6

Subinfraturma NODATI Dybová and Jachowicz, 1957

Genus Lophotriletes (Naumova) Potonié and Kremp, 1954

Occurrence: rare in VFIG 1

aff. Lophotriletes gibbosus (Ibrahim) Potonié and Kremp, 1955

Occurrence: rare in VFIG 1

Subinfraturma BACULATI Dybová and Jachowicz, 1957

Genus Raistrickia (Schopf, Wilson and Bentall) Potonié and Kremp, 1954

Occurrence: frequent in VFIG 1 and present in SUS 5 and 6

Raistrickia carbondalensis Peppers, 1970 (Fig. 5c)

Occurrence: rare in VFIG 1

Raistrickia fulva Artuz, 1957 (Fig. 61)

Occurrence: present in SUS 5

Raistrickia sp aff. R. corynoges Sullivan, 1968 (Fig. 6m)

Occurrence: present in SUS 5

Raistrickia spp.

Occurrence: frequent in VFIG 1 and present in SUS 5 and 6

Infraturma MURORNATI Potonié and Kremp, 1954

Genus Microreticulatisporites (Knox) Potonié and Kremp 1954

Occurrence: rare in VFIG 1

Microreticulatisporites microreticulatus Knox, 1950 (Fig. 6j)

Occurrence: present in SUS 6

aff. Microreticulatisporites $\mathrm{sp}$.

Occurrence: rare in VFIG 1

Genus Convolutispora Hoffmeister, Staplin and Malloy, 1955

Occurrence: present in SUS 6

Convolutispora sp. (Fig. 6a)

Occurrence: present in SUS 6

Subturma ZONOTRILETES Waltz, 1935

Infraturma AURICULATI Dettmann, 1963

Genus Triquitrites (Wilson and Coe) Potonié and Kremp, 1954

Occurrence: common in VFIG 1 and present in SUS 5 and 6 
Triquitrites sp. cf. T. desperatus Potonié and Kremp, 1955 (Fig. 5i)

Occurrence: rare in VFIG 1

Triquitrites priscus Kosanke 1950 (Fig. 5j)

Occurrence: rare in VFIG 1

Triquitrites sp. cf. T. sculptilis Balme, 1952 (Fig. 6q)

Occurrence: rare in VFIG 1, present in SUS 6

Triquitrites sp. aff T. triturgidus (Loose) Schopf, Wilson and Bentall, 1944

Occurrence: rare in VFIG 1

Triquitrites spp.

Occurrence: common in VFIG 1 and present in SUS 5 and 6

Infraturma TRICRASSATI Dettmann, 1963

Genus Reinschospora Schopf, Wilson and Bentall, 1944

Occurrence: rare in VFIG 1

Reinschospora sp.

Occurrence: rare in VFIG 1

Infraturma CINGULATI Dettmann, 1963

Genus Cadiospora (Kosanke) Turner, 1993

Occurrence: frequent in VFIG 1

Cadiospora magna Kosanke, 1950 (Fig. 4b)

Occurrence: frequent in VFIG 1

Genus Reticulatisporites (Ibrahim) Neves, 1964

Occurrence: frequent in VFIG 1

aff. Reticulatisporites lacunosus Kosanke, 1950

Occurrence: rare in VFIG 1

Reticulatisporites sp. cf. R. reticulatus Ibrahim, 1933 (Fig. 5d)

Occurrence: frequent in VFIG 1

Genus Savitrisporites Bharadwaj, 1955

Occurrence: present in SUS 5

? Savitrisporites sp. (Fig. 6n)

Occurrence: present in SUS 5

Subturma ZONOLAMINATITRILETES Smith and Butterworth, 1967

Infraturmae CRASSITI (Bharadwaj and Venkatachala) Smith and Butterworth, 1967 and CINGULICAVATI Smith and Butterworth, 1967

Genus Cirratriradites Wilson and Coe, 1940

Occurrence: frequent in VFIG 1

Cirratriradites sp. cf. C. elegans (Waltz) Potonié and Kremp, 1956 (Fig. 4e)

Occurrence: rare in VFIG 1

Cirratriradites sp.

Occurrence: frequent in VFIG 1

Genus Crassispora Bharadwaj, 1957

Occurrence: Very common in VFIG 1 and present in SUS 5 and 6

Crassispora kosankei (Potonié and Kremp) Bharadwaj, 1957 (Fig. 4g; Fig. 6b)

Occurrence: Very common in VFIG 1 and present in SUS 5 and 6

Crassispora sp. cf. C. maculosa (Knox) Sullivan, 1968 (Fig. 6c)

Occurrence: present in SUS 5

Crassispora $\mathrm{sp}$.

Occurrence: present in SUS 5 and 6

Genus Densosporites (Berry) Jansonius, Smith and Staplin, 1964

Occurrence: Very common in all sections

Densosporites sp. cf. D. anulatus (Loose) Smith and Butterworth, 1967

Occurrence: rare in VFIG 1

Densosporites crassigranifer Artuz, 1957

Occurrence: rare in VFIG 1

Densosporites sp. cf. D. lobatus Kosanke, 1950 (Fig. 6e)

Occurrence: frequent in VFIG 1 and present in SUS 6

Densosporites gracilis Smith and Butterworth, 1967 (Fig. 4h)

Occurrence: rare in VFIG 1

Densosporites sp. cf. D. pseudoanulatus Kosanke, 1950 (Fig. 4i)

Occurrence: rare in VFIG 1

Densosporites sp. cf. D. sphaerotriangularis Kosanke, 1950
Occurrence: frequent in VFIG 1

Densosporites spp.

Occurrence: Very common in VFIG 1 and present in SUS 5

Genus Lundbladispora (Balme) Playford, 1965

Occurrence: common in VFIG 1

Lundbladispora gigantea (Alpern) Doubinger, 1968 (Fig. 4p)

Occurrence: frequent in VFIG 1

Lundbladispora sp.

Occurrence: frequent in VFIG 1

Genus Lycospora (Schopf, Wilson and Bentall) Somers, 1972

Occurrence: very common in VFIG 1 and present in SUS 5 and 6

Lycospora parva Kosanke, 1950

Occurrence: rare in VFIG 1

Lycospora pusilla (Ibrahim) Somers, 1972 (Fig. 4q)

Occurrence: common in all sections

Lycospora sp.

Occurrence: common in VFIG 1 and present in SUS 6

Genus Radiizonates Staplin and Jansonius, 1964

Occurrence: rare in VFIG 1

Radiizonates tenuis (Loose) Butterworth and Smith, 1964 (Fig. 5b)

Occurrence: rare in VFIG 1

Genus Westphalensisporites Alpern, 1959

Occurrence: frequent in VFIG 1 and present in SUS 5

Westphalensisporites irregularis Alpern, 1959 (Fig. 51)

Occurrence: frequent in VFIG 1 and present in SUS 5

Suprasubturma PSEUDOSACCITRILETES Richardson, 1965

Infraturma MONOPSEUDOSACCITI Smith and Butterworth, 1967

Genus Endosporites Wilson and Coe, 1940

Occurrence: frequent in VFIG 1

Endosporites globiformis (Ibrahim) Schopf, Wilson and Bentall, 1944 (Fig. $4 \mathrm{k})$

Occurrence: frequent in VFIG 1

Subturma PERINOTRILETES Erdtman, 1947

Genus Vestispora (Wilson and Hoffmeister) Wilson and Venkatachala, 1963

Occurrence: rare in VFIG 1, present in SUS 6

Vestispora sp. cf. V. costata (Balme, 1952) Spode in Smith and Buterworth, 1967 (Fig. 6t)

Occurrence: present in SUS 6

Vestispora $\mathrm{sp.}$

Occurrence: rare in VFIG 1

Turma MONOLETES Ibrahim, 1933

Subturma AZONOMONOLETES Luber, 1935

Infraturma LAEVIGATOMONOLETI Dybová and Jachowicz, 1957

Genus Laevigatosporites Ibrahim, 1933

Occurrence: common in VFIG 1

Laevigatosporites maximus (Loose) Potonié and Kremp, 1954

Occurrence: frequent in VFIG 1

Laevigatosporites medius Kosanke, 1950

Occurrence: present in SUS 5

Laevigatosporites minimus (Wilson and Coe) Schopf, Wilson and Bentall, 1944 (Fig. 6h)

Occurrence: present in SUS 5

Laevigatosporites sp. cf. L. perminutus Alpern, 1958

Occurrence: present in SUS 5 and 6

Laevigatosporites $\mathrm{sp}$. cf. L. ovalis Kosanke, 1950

Occurrence: present in SUS 5

Laevigatosporites sp. cf. L. robustus Kosanke, 1950

Occurrence: rare in VFIG 1 
Laevigatosporites sp. cf. L. vulgaris (Ibrahim) Alpern and Doubinger, 1973 (Fig. 4n)

Occurrence: frequent in VFIG 1 and present in SUS 5

Laevigatosporites spp.

Occurrence: frequent in VFIG 1, very common is SUS 5 and present in SUS 6

Infraturma SCULPTATOMONOLETI Dybová and Jachowicz, 1957

Genus Cheiledonites Doubinger, 1957

Occurrence: frequent in VFIG 1

Cheiledonites sp. (Fig. 4d)

Occurrence: frequent in VFIG 1

Genus Punctatosporites Ibrahim, 1933

Occurrence: rare in VFIG 1, and present in SUS 5 and 6

Puntactosporites cf. minutus

Occurrence: rare in VFIG 1 and present in SUS 6

Punctatosporites sp. (Fig. 6k)

Occurrence: rare in VFIG 1, and present in SUS 5 and 6

Genus Torispora Balme, 1952

Occurrence: rare in VFIG 1

cf. Torispora securis (Balme) Alpern, Doubinger and Horst, 1973 (Fig. 5h)

Occurrence: rare in VFIG 1

Genus Thymospora (Wilson and Venkatachala) Alpern and Doubinger, 1973 Occurrence: frequent in VFIG 1

Thymospora sp. cf. T. pseudothiessenii (Kosanke) Alpern and Doubinger, 1973 (Fig. 5g)

Occurrence: frequent in VFIG 1

Anteturma POLLENITES Potonié, 1931

Turma SACCITES Erdtmann, 1947

Subturma MONOSACCITES Potonié and Kremp, 1954

Infraturma TRILETESACCITI Leschik, 1955

Genus Cordaitina (Samoilovich) Hart, 1965

Occurrence: rare in VFIG 1

Cordaitina sp. (Fig. 4f)

Occurrence: rare in VFIG 1

Genus Latensina Alpern, 1958

Occurrence: common in VFIG 1

Latensina trileta Alpern, 1958 (Fig. 4o)

Occurrence: frequent in VFIG 1

Latensina sp.

Occurrence: frequent in VFIG 1

Genus Wilsonites Kosanke, 1950

Occurrence: very common in VFIG 1

Wilsonites sp. aff. W. delicatus Kosanke, 1950

Occurrence: frequent in VFIG 1

Wilsonites sp. cf. W. vagus Inossova, 1976 (Fig. 5m)

Occurrence: frequent in VFIG 1

Wilsonites spp.

Occurrence: common in VFIG 1

Infraturma ALETESACCITI Leschik, 1955
Genus Florinites Schopf, Wilson and Bentall, 1944

Occurrence: very common in VFIG 1 and present in SUS 5

Florinites sp. cf. bederi Pittau del Río, Cotza, Ronchi, Santi and Giannotti, 2008 (Fig. 41)

Occurrence: frequent in VFIG 1

Florinites sp. cf. F. diversiformis Kosanke, 1950

Occurrence: frequent in VFIG 1

Florinites sp. cf. F. junior Potonié and Kremp, 1954 (Fig. 4m)

Occurrence: frequent in VFIG 1

aff. Florinites pellucidus (Wilson and Coe) Wilson, 1958

Occurrence: rare in VFIG 1

Florinites sp. cf. F. similis Kosanke, 1950

Occurrence: frequent in VFIG 1

Florinites visendus (Ibrahim) Schopf, Wilson and Bentall, 1944

Occurrence: frequent in VFIG 1

Florinites spp. (eg. Fig. 6f)

Occurrence: common in VFIG 1 and present in SUS 5

Infraturma VESICULOMONORADITI Pant, 1954

Genus Potonieisporites (Bharadwaj) Bharadwaj, 1964

Occurrence: frequent in VFIG 1

Potonieisporites sp.

Occurrence: frequent in VFIG 1

Subturma DISACCITES Cookson, 1947

Non-striatted Disaccites pollen (unestablished systematic; Fig. 4j)

Occurrence: rare in VFIG 1

Infraturma DISACCITRILETI Leschik, 1955

Genus Pityosporites Seward, 1914

Occurrence: frequent in VFIG 1

Pityosporites sp.

Occurrence: frequent in VFIG 1

Subturma POLYSACCITES Cookson, 1947

Genus Alatisporites Ibrahim, 1933

Occurrence: frequent in VFIG 1

Alatisporites sp. (Fig. 4a)

Occurrence: frequent in VFIG 1

Turma PLICATES Potonié and Kremp, 1954

Subturma PRAECOLPATES Potonié and Kremp, 1954

Genus Schopfipollenites Potonié and Kremp, 1954

Occurrence: abundant in VFIG 1, and present in SUS 5 and 6

Schopfipollenites ellipsoides (Ibrahim) Potonié and Kremp, 1954 (Fig. 5e)

Occurrence: abundant in VFIG 1

Schopfipollenites ovalis Schwartsman, 1976

Occurrence: very common in VFIG 1

Schopfipollenites parvus Schwartsman, 1976

Occurrence: common in VFIG 1

Schopfipollenites sp. (Fig. 6o)

Occurrence: common in VFIG 1, and present in SUS 5 and 6

Unknown suprageneric assignation

Genus Trinidulus Felix and Paden, 1964

Occurrence: present in SUS 6

Trinidulus diamphidios Felix and Paden, 1964 (Fig. 6p) 